Report of Investigation 2021-3

\title{
EROSION EXPOSURE ASSESSMENT OF INFRASTRUCTURE IN ALASKA COASTAL COMMUNITIES
}

Richard M. Buzard, Mark M. Turner, Katie Y. Miller, Donald C. Antrobus, and Jacquelyn R. Overbeck
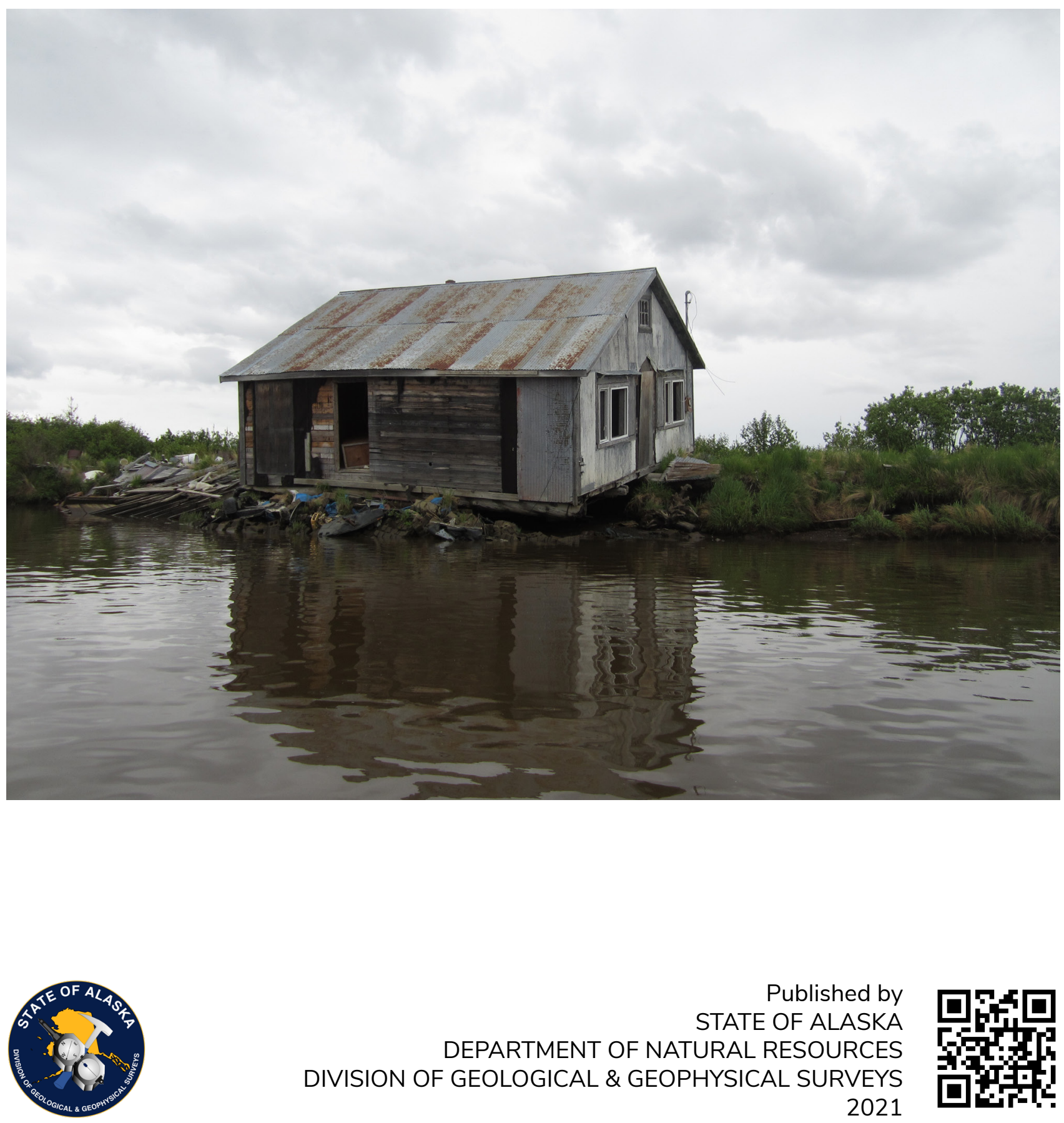



\section{EROSION EXPOSURE ASSESSMENT OF INFRASTRUCTURE IN ALASKA COASTAL COMMUNITIES}

Richard M. Buzard, Mark M. Turner, Katie Y. Miller, Donald C. Antrobus, and Jacquelyn R. Overbeck

Report of Investigation 2021-3

State of Alaska

Department of Natural Resources

Division of Geological \& Geophysical Surveys 


\section{STATE OF ALASKA}

Mike Dunleavy, Governor

\section{DEPARTMENT OF NATURAL RESOURCES}

Corri A. Feige, Commissioner

\section{DIVISION OF GEOLOGICAL \& GEOPHYSICAL SURVEYS}

Steve Masterman, State Geologist and Director

Publications produced by the Division of Geological \& Geophysical Surveys (DGGS) are available to download from the DGGS website (dggs.alaska.gov). Publications on hardcopy or digital media can be examined or purchased in the Fairbanks office:

Alaska Division of Geological \& Geophysical Surveys 3354 College Rd., Fairbanks, Alaska 99709-3707

Phone: (907) 451-5010 Fax (907) 451-5050

dggspubs@alaska.gov|dggs.alaska.gov

\section{DGGS publications are also available at:}

Alaska State Library,

Historical Collections \& Talking Book Center

395 Whittier Street

Juneau, Alaska 99811

Alaska Resource Library and Information Services (ARLIS)

3150 C Street, Suite 100

Anchorage, Alaska 99503

\section{Suggested citation:}

Buzard, R.M., Turner, M.M., Miller, K.Y., Antrobus, D.C., and Overbeck, J.R., 2021, Erosion Exposure Assessment of Infrastructure in Alaska Coastal Communities: Alaska Division of Geological \& Geophysical Surveys Report of Investigation 2021-3, 23 p. https://doi.org/10.14509/30672
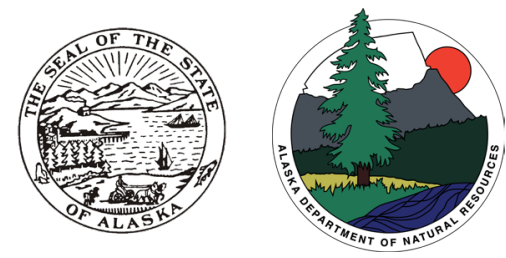


\section{Contents}

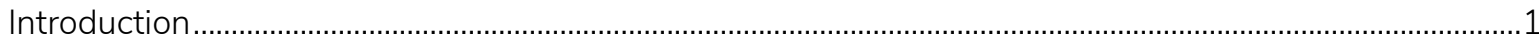

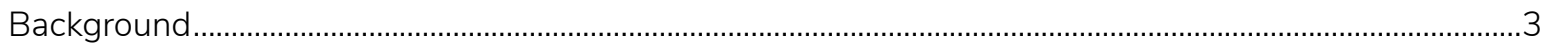

Scope of This Report and Community-Specific Reports .............................................................................

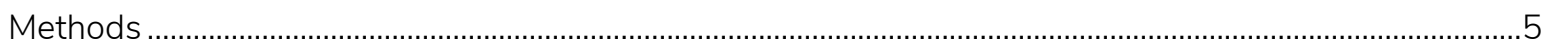

Shoreline Change Assessment .........................................................................................................

Suitable Shoreline Proxies for Erosion Forecasting .............................................................................

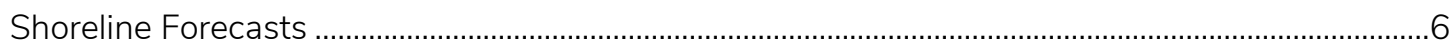

Infrastructure Data and Erosion Exposure .........................................................................................

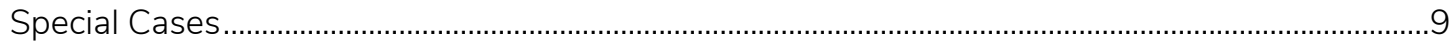

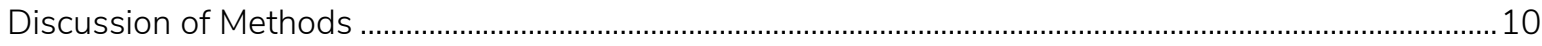

Advantages and Limitations of Linear Regression Erosion Forecasts ............................................. 10

Infrastructure and Replacement Cost .................................................................................................. 14

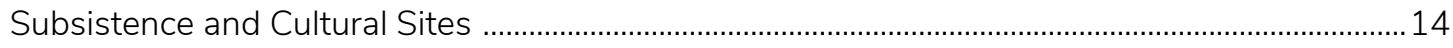

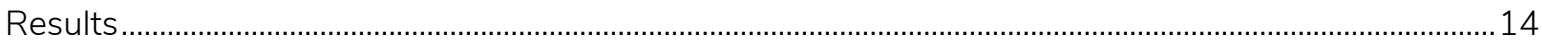

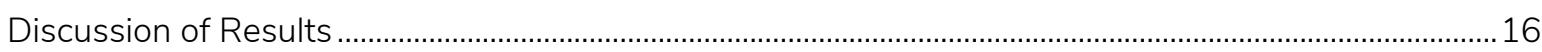

Intended Use of Erosion Exposure Assessments ...............................................................................17

Consequences of Unclear and Exaggerated Erosion Forecast Language ........................................17

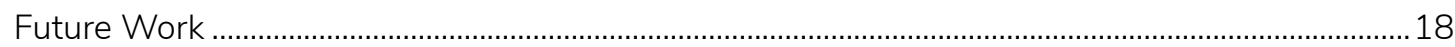

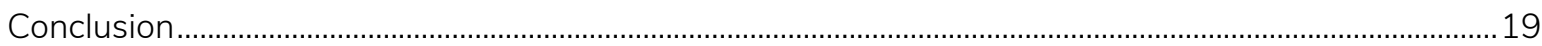

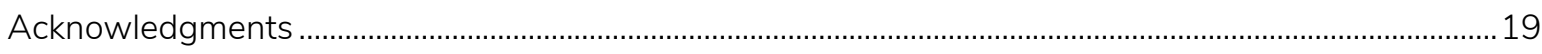

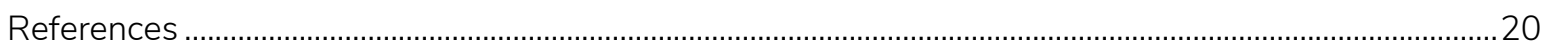

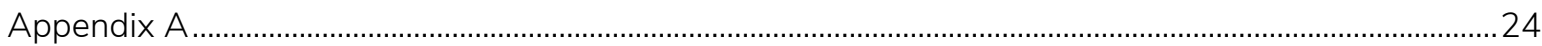

\section{Figures}

Figure 1. Aerial images comparing erosion in Napakiak from 1952 to 2019.............................................

Figure 2. Aerial images comparing erosion in Kotlik from the 1950s to present...........................................

Figure 3. Location of erosion exposure assessments completed with this report........................................ 4

Figure 4. Mean high water and vegetation shorelines in Hooper Bay show different

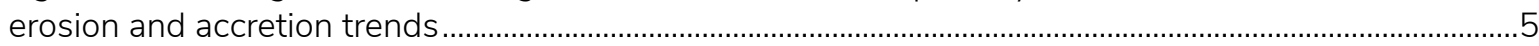

Figure 5. Diagram depicting linear erosion forecast method .........................................................................7

Figure 6. The history of the Alakanuk River is shown with the 1951 river footprint ...............................10

Figure 7. Diagram showing the unpredictable erosion of the Kanektok River in Quinhagak

and the re-routing of the Twin Hills River from 1952 to 2016................................................................11

Figure 8. Color infrared and aerial image showing the potential erosion impacts in Dillingham ...........12

Figure 9. The shoreline history of Shishmaref shows erosion across the island and

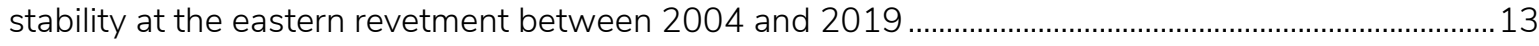

Figure 10. Examples of erosion forecast and erosion exposure map products...........................................15

Figure 11. Percent of total replacement cost of infrastructure forecast to be exposed to erosion by the 2070s for each of the 48 communities assessed ..................................................................16

\section{Tables}

Table 1. Generic cost of infrastructure in rural Alaska

communities determined by the Alaska Native Tribal Health Consortium. 



\title{
EROSION EXPOSURE ASSESSMENT OF INFRASTRUCTURE IN ALASKA COASTAL COMMUNITIES
} Richard M. Buzard ${ }^{1}$, Mark M. Turner ${ }^{1}$, Katie Y. Miller ${ }^{1}$, Donald C. Antrobus ${ }^{2}$, and Jacquelyn R.
Overbeck

\begin{abstract}
Alaska communities located along coastlines and tidally influenced rivers are vulnerable to coastal erosion. These communities face decisions that require advance planning, such as implementing shore protection or moving infrastructure. To aid in erosion planning, we estimate erosion exposure for 48 communities from the Bering to the Beaufort seas. We conduct a shoreline change assessment, forecast 60 years of erosion, and estimate the replacement cost of infrastructure in the forecast area. Of 48 communities analyzed, 33 have infrastructure within the erosion forecast area. Fifteen communities comprise 90 percent of the total replacement cost. Eleven of these, and 80 percent of total estimated cost, are in the Yukon-Kuskokwim Delta. More than 40 percent of the estimated cost is forecast to occur by the late 2030s.

A summary of findings and map(s) of erosion forecast areas are provided for each community where an assessment could be performed. Erosion forecasts require a clearly identifiable shoreline that can be tracked through time in aerial imagery, as well as no major coastal protection structures in the forecast area. Erosion forecasts are not suitable for 12 communities, so we provide recommendations to address erosion concerns in those community assessment reports. The assessment conducted here is a tool for developing local hazard mitigation plans and strategies to address erosion. There are methodological limitations to linear shoreline change measurements, forecasts, and infrastructure replacement costs. Total costs are not reported in this summary due to these limitations. Users must incorporate expertise and local knowledge when interpreting results.
\end{abstract}

\section{INTRODUCTION}

A critical component of risk management is identifying exposure - the situation of tangible assets in a hazard-prone area (Crichton, 1999; United Nations Office for Disaster Risk Reduction, www.undrr.org/terminology/exposure). In this assessment, we estimate the amount of infrastructure exposed to erosion in 48 Alaska communities from the Bering to the Beaufort seas. We conduct a shoreline change analysis, forecast 60 years of erosion, and estimate the replacement cost of infrastructure in the forecast area. The products can be incorporated into multi-hazard assessments such as community and statewide hazard mitigation plans and assessments (for example, University of Alaska Fairbanks [UAF] and others, 2019). The discussion section of this summary report explains the intended use and limitations of exposure assessments as an element of risk assessment.

Alaska's Bering, Chukchi, and Beaufort coasts are dotted with many rural communities that are vulnerable to erosion (UAF and others, 2019). Based on an analysis of shoreline positions from the 1950 s to 2010 s, at least 28 of these commu-

${ }^{1}$ Alaska Division of Geological \& Geophysical Surveys, 3354 College Rd., Fairbanks, Alaska 99709-3707

${ }^{2}$ Alaska Native Tribal Health Consortium, 4000 Ambassador Drive, Anchorage, Alaska 99508 
nities experience erosion rates greater than 3.3 feet per year (1 meter per year; Overbeck and others, 2020). Coastal erosion in this region is driven by wave and storm activity (U.S. Army Corps of Engineers [USACE], 2009a) and influenced by local geology, hydrology, permafrost thaw, flooding, reductions in sea ice, human activity, and many other factors (Farquharson and others, 2018; Jones and others, 2018; Overbeck and others, 2020). Rapid erosion rates have resulted in the relocation of entire villages, including Napakiak (see example in fig. 1), Meshik (now Port Heiden; Kinsman and others, 2014), and currently Newtok (Native Village of Newtok and others, 2015). Even communities with slow erosion rates face elevated exposure if infrastructure is near the coastline (UAF and others, 2019; Overbeck and others, 2020; fig. 2).

All communities in northern and western Alaska have increased the amount and value of infrastructure over the past 70 years: runways doubled in size to accommodate larger planes; bulk fuel tank farms, wastewater lagoons, and landfills have been installed and expanded; drinking water systems, larger schools, more homes, and new neighborhoods have been built (fig. 2). These additions improved community health and safety (U.S. Congress, 1994; U.S. Arctic Research Commission, 2015). However, in many places new infrastructure was placed near the coast-establishing a community footprint closer to shorelines. Communities are actively and continually addressing erosion by constructing and maintaining shoreline protection structures, moving individual buildings, and relocating to new sites.

Rural Alaska communities are uniquely vulnerable to hazards because most are disconnected from the road system, are only accessible by plane, require boat or barge access for supplies, and have an isolated grid for utilities and infrastructure. Critical infrastructure-"facilities that provide essential products and services to the general public"-are often singular (Alaska Division of
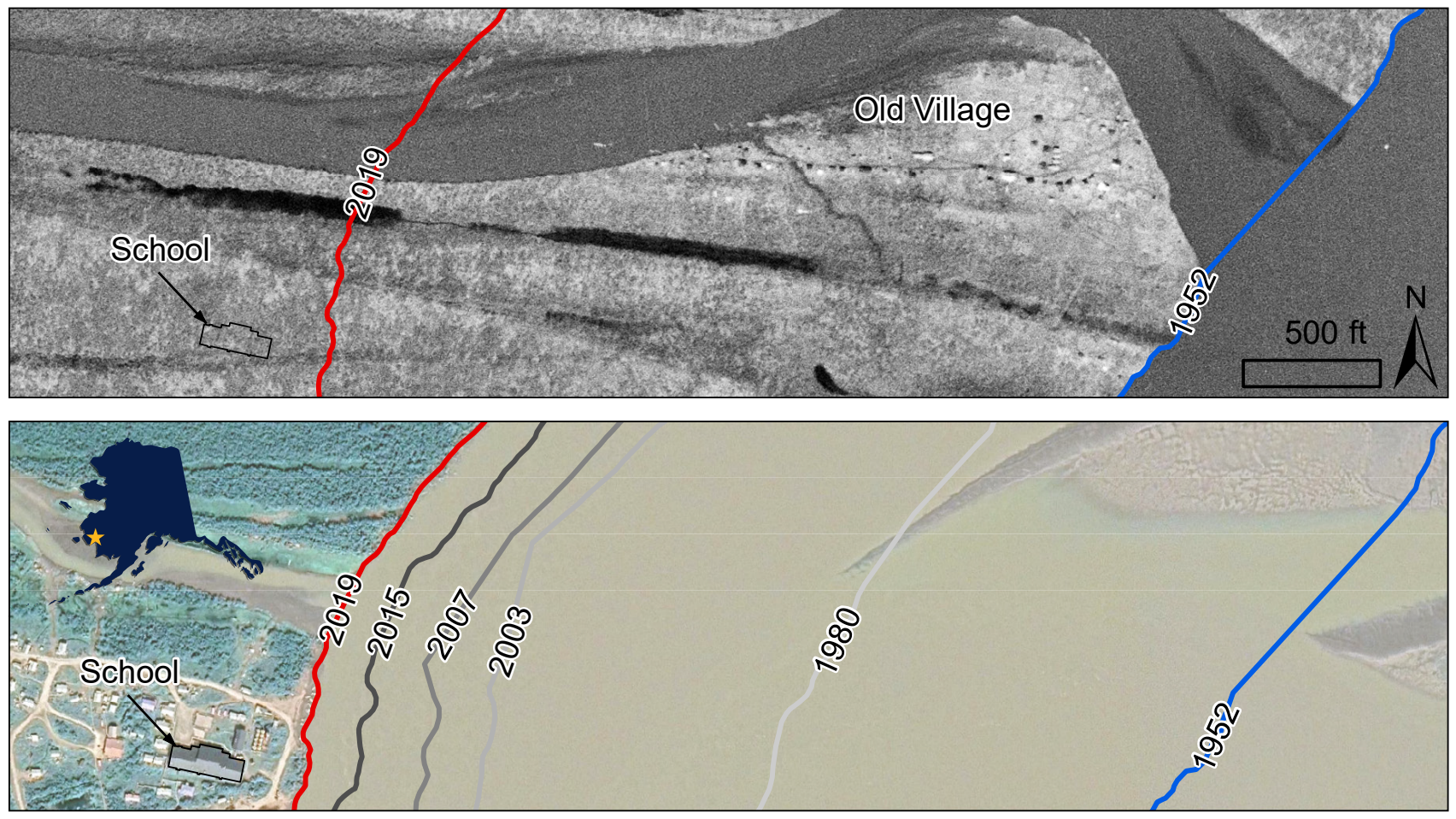

Figure 1. (Top) This aerial image from 1952 shows the former location of Napakiak (with the 2019 school and shoreline superimposed). The entire village has since relocated from the old site due to erosion. (Bottom) Erosion now threatens the current school and surrounding infrastructure. Erosion rates averaged $38 \mathrm{ft}$ per year over 67 years, and the school is $200 \mathrm{ft}$ from the 2019 shoreline (Overbeck and others, 2020). 

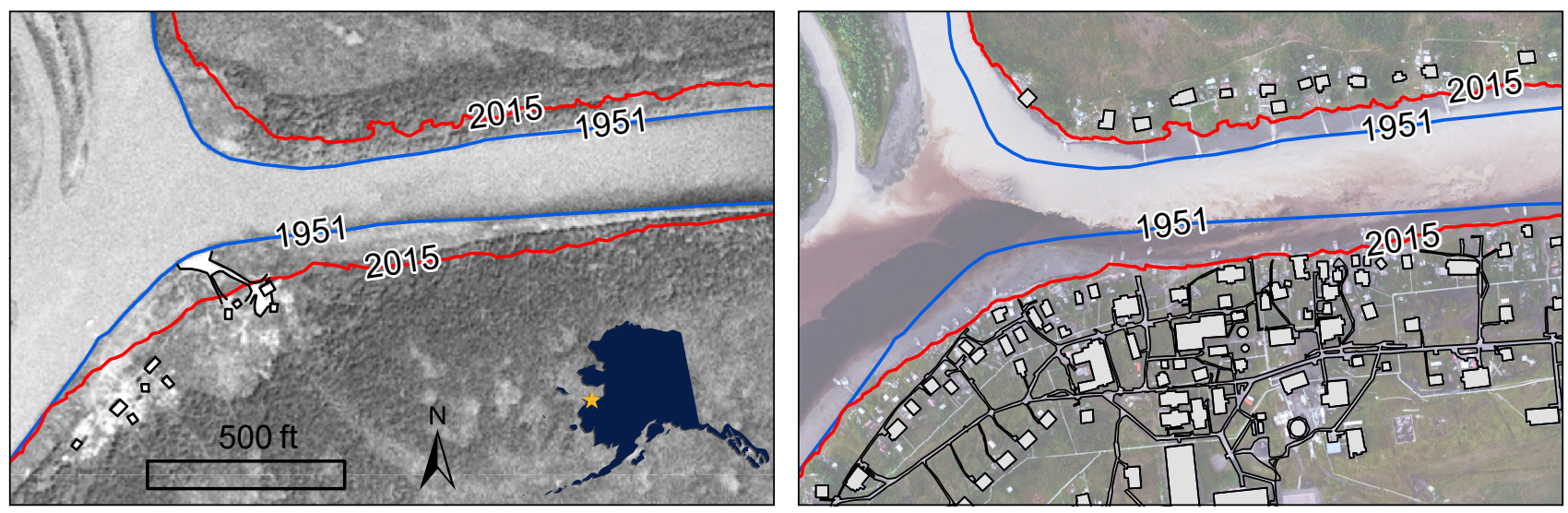

Figure 2. (Left) Kotlik was a small trading hub in the 1950s (Himes-Cornell and others, 2013). In 1959, the Bureau of Indian Affairs built a school in Kotlik, and neighboring communities moved there to attend. (Right) The community footprint rapidly expanded with housing, utility systems, boardwalks, and other infrastructure. Erosion is relatively slow, but pervasive, and undermines many coastal structures (Overbeck and others, 2020).

Homeland Security \& Emergency Management [DHS\&EM], 2018). These include the airport, barge landing, fuel storage, wastewater treatment, landfill, and washeteria (commonly the only source of treated drinking water and shower/laundry facilities). DHS\&EM (2018) explains, "Due to many of Alaska's communities' remote rural location... most all facilities are deemed 'critical' to a community or agency's survival." Without backup options, the loss of any one facility can result in the loss of essential services to the entire community.

There is great need for erosion exposure assessments in rural Alaska communities. Local and statewide hazard assessments speculate erosion will soon impact subsistence sites, homes, and critical infrastructure (U.S. General Accounting Office [GAO], 2003; GAO, 2009; Immediate Action Workgroup [IAWG], 2009; USACE, 2009a; UAF and others, 2019). However, in the absence of quantitative analyses, hazard assessments often err on the side of bleak narratives (see examples in "Discussion" section). Yoder (2018) explains, "In Alaska, many residents have expressed concern and a feeling of depression related to the uncertainty of the scope and magnitude of potential climate change." This uncertain narrative also led to costly, rushed responses. Such is the case in Shishmaref where a series of shoreline stabilization efforts have been employed since the 1940s which ultimately failed, until the placement of boulder rock revetments in the 2000s (Mason and others, 2012), which still do not extend along the entire area at risk to erosion. Larsen and others (2008) estimate Alaska's infrastructure upkeep costs may rise by 10 to 12 percent by 2080 due to climate change, but informed adaptation strategies can significantly reduce costs. Quantitative erosion exposure assessments can aid Alaska communities with informed resilience planning and alleviate concerns over the unknown.

\section{BACKGROUND}

The first systematic documentation of erosion in Alaska occurred when the Alaska Division of Community and Regional Affairs (DCRA, 1982) collected written surveys and interviews from communities and agencies. DCRA (1982) found that 169 of 213 Alaska Native villages experienced erosion and/or flooding, with the greatest impacts felt along coasts and tidally influenced rivers. GAO (2003) reached similar conclusions in an updated survey, which sparked the Baseline Erosion Assessment by USACE (2009a) (IAWG, 2009). The USACE assessment provided an unprecedented look into erosion across the state and recommended action based on level of threat from erosion using three categories: priority action, monitor conditions, and minimal erosion. The USACE (2009a) results have been used to imple- 
ment federal shoreline protection and relocation projects. Ten years later, UAF and others (2019) investigated erosion risk, but for many communities the best existing erosion documentation was still the USACE (2009a) Baseline Erosion Assessment. Ultimately, there remains a need for quantitative data to adequately assess erosion exposure for Alaska communities. Overbeck and others (2020) computed linear shoreline change rates using aerial imagery from approximately the 1950 s to the modern era (2015-18) for coastal communities. Our study builds upon this effort by estimating infrastructure exposure to future erosion.

\section{SCOPE OF THIS REPORT AND COMMUNITY-SPECIFIC REPORTS}

This report discusses the methods used to assess exposure of infrastructure to erosion in Alaska communities. Results for each community are provided in a separate community report and map(s) where applicable (fig. 3). The products, listed below, are designed to aid in near- and long-term planning for erosion mitigation and adaptation:

1. Community report describing observed erosion, mitigation, forecast results, and special considerations.

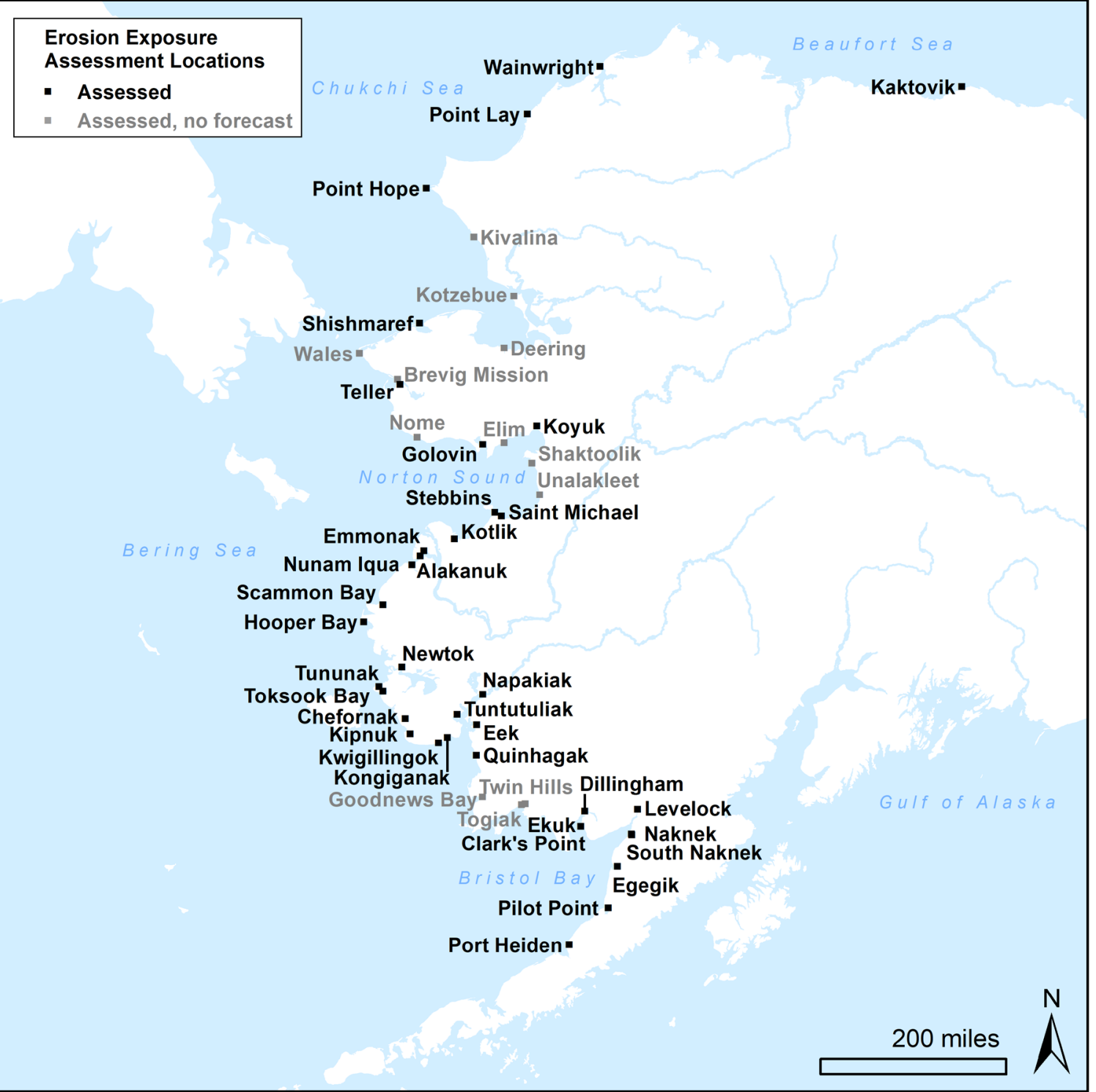

Figure 3. Location of erosion exposure assessments completed with this report. 
2. Erosion forecast map(s) showing the area of land exposed to erosion for 20-, 40-, and 60 -year intervals along with model uncertainty.

3. Erosion exposure map(s) highlighting infrastructure exposed to erosion in 20,40 , and 60 years.

\section{METHODS}

To assess erosion exposure of infrastructure, we conduct a shoreline change assessment, forecast 60 years of erosion continuing at the historical rate, and estimate the replacement cost of infrastructure in the forecast area.

\section{Shoreline Change Assessment}

In coastal studies, the term "shoreline" can be defined by many features, such as the mean high water line (MHW), land-water interface (LWI), or vegetation line (Boak and Turner, 2005). Different types of shorelines can exhibit different patterns of erosion and accretion. Some shoreline types have greater relevance depending on the study focus. For this assessment, the relevant shoreline represents a discernible feature at which infrastructure cannot be developed seaward due to active coastal or riverine processes. This is most commonly the vegetation line, riverbank, or bluff top edge. While MHW and LWI generally parallel vegetation, their position and change rates are subject to greater uncertainty due to short- and long-term fluctuations in the tidal regime (Boak and Turner, 2005). Water lines can also represent cyclical beach change or an erosional regime altogether different from nearby vegetation lines at the boundary of developable land (Ruggiero

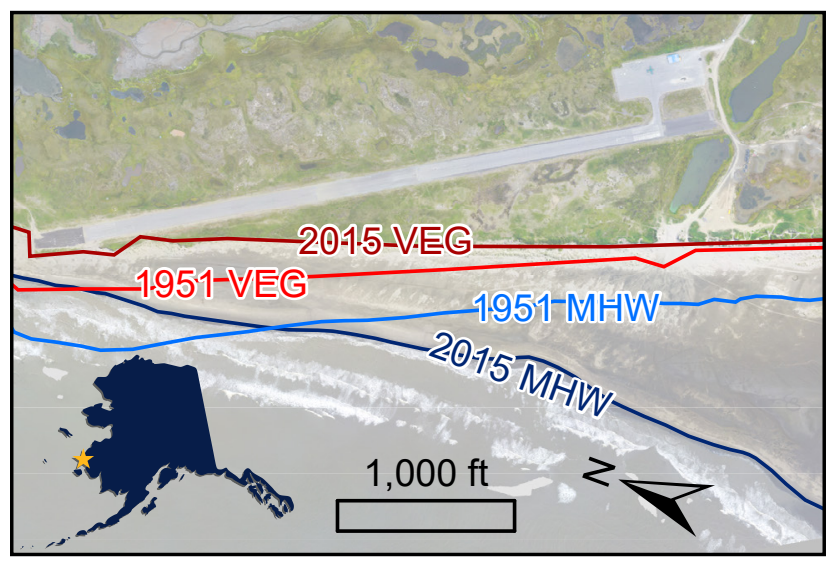

and others, 2005; fig. 4). For these reasons, we forecast vegetation-based shorelines where possible.

Overbeck and others (2020) delineated or collected shoreline data for 48 Alaska communities. Sixty percent of the shorelines from Overbeck and others (2020) are vegetation lines, and the remaining are HWL or LWI. Where needed, we delineate shorelines using the vegetation line, riverbank, or bluff top edge using orthoimagery datasets and methods described by Overbeck and others (2020).

Calculating erosion rates requires at least two shorelines from different dates, but more shorelines at regular time steps can improve accuracy (Crowell and others, 2018). For this study, each site has at least three shorelines: one recent shoreline (2015 to 2019) and two or more historical shorelines (1950s, 1980s, 2000s), spanning over 60 years total. Multiple authors review new delineations and compare them to oblique imagery from the ShoreZone Partnership (www.shorezone.org) in order to identify delineation errors and find the best feature to trace. Shoreline delineation uncertainty is calculated as the root-sum-of-squares of the imagery orthorectification error, ground sampling distance, and digitizer error (see Overbeck and others [2020] for a full description).

Shoreline change rates are calculated using the Digital Shoreline Analysis System tool (DSAS; Himmelstoss and others, 2018). Virtual transects are cast perpendicular to the shoreline at 25-meter spacing. Along each transect, DSAS measures the position and distance between shorelines over time. Erosion rates are calculated using the weighted linear regression rate of change statistic and uncertainty at a 90 percent confidence interval when at least three shorelines are present (Himmelstoss and others, 2018).

Figure 4. Mean high water (MHW; blue) and vegetation (red) shorelines at Hooper Bay show different erosion and accretion trends. A sand lobe has migrated in front of the airport, showing a strong accretion signal; however, storm surge still reaches the vegetation line, causing erosion that threatens the runway. This example shows the importance of using the vegetation line to calculate the erosion trend fronting the Hooper Bay runway. 
Shorelines are generally linear alongshore features, but at finer scales they are not always straight lines. Shorelines can fluctuate by several meters toward and away from the water, especially near a river outlet or beach access road where a vegetation line turns sharply inland. The DSAS transect method is sensitive to these fluctuations, which are outliers to the neighboring shoreline position. If a forecast is made from an outlier, the deviation propagates to create an unrealistic future shoreline (eroding or stabilizing at a rate vastly different from the nearest transects). We reduce the influence of outliers by generalizing shoreline change rates using a 3-transect moving window to compute the weighted mean erosion rate (WMER) and uncertainty (WMCI90), similar to Genz and others (2007). This practice also reduces uncertainty when neighboring transects have agreeing values (in other words, if three neighboring transects have the same erosion rate, it is more certain that the measured rate is the true rate). However, if the uncertainty was already small, the weighted uncertainty can approach $0.0 \mathrm{~m}$ per year, which is unrealistic. To avoid overconfident forecasts, a cutoff of $0.1 \mathrm{~m}$ per year is applied to the forecast uncertainty. With this cutoff, a 60-year erosion forecast will have at least a 6-meter uncertainty.

\section{Suitable Shoreline Proxies for Erosion Forecasting}

Delineating the appropriate shoreline proxy is a critical aspect to shoreline change analyses. The term "proxy" is used because shorelines are interpreted from photo-identifiable features rather than measured directly (such as with GPS or on an elevation model), and this process introduces uncertainty. We find that the vegetation line (including bluff top edge or scarp) is the most suitable shoreline for measuring erosion of developable land-the landward-most features eroded by high water events are bluffs, scarps, and vegetation lines (Boak and Turner, 2005). These features are typically easier to interpret in aerial imagery than water line proxies like MHW or LWI. Challenges still arise, especially when dense vegetation obscures the top and toe of a bluff. We address this issue by using elevation models or oblique imagery to identify the correct vegetation line proxy. This validation technique is effective with recent, high-resolution, multiband orthoimagery, but less so for older, coarse, panchromatic orthoimagery. Fortunately for this effort, dense vegetation is uncommon in most assessed communities. A second accuracy limitation comes with the datasets themselves: poorly orthorectified imagery causes horizontal offsets and relief displacement (Crowell and others, 1991). This issue is most common for tall, steep cliffs orthorectified from few images. Historical orthomosaics were orthorectified using few images, but such geographic features are uncommon for communities in our assessment, so we assume this error is the same as the image horizontal uncertainty.

\section{Shoreline Forecasts}

We use the WMER and WMCI90 to forecast mean and maximum distances of future shorelines. The mean distance $\left(d_{\mu}\right)$ is the WMER multiplied by the number of years into the future $\left(t_{y}\right.$; equation 1). The maximum distance $\left(d_{\text {max }}\right)$ accommodates the uncertainty in the shoreline forecast and is calculated by adding WMCI90 to WMER, then multiplying by 60 years (equation 2).

$$
\begin{gathered}
d_{\mu}=\text { WMER } \times t_{y} \\
d_{\max }=(\text { WMER }+ \text { WCI90 }) \times t_{60}
\end{gathered}
$$

$$
\begin{aligned}
& d_{\mu}=\text { mean erosion distance } \\
& d_{\max }=\text { maximum erosion distance } \\
& t_{y}=\text { number of years from most recent shoreline }
\end{aligned}
$$

The conceptual diagram in figure 5 illustrates the erosion exposure assessment method. Erosion rates, based on historical shoreline positions (transparent to modern shoreline), are forecast to continue at a linear pace for 20, 40, and 60 years from the most recent shoreline (black solid line). The uncertainty area (light blue) shows the maximum erosion distance forecast within a 90 


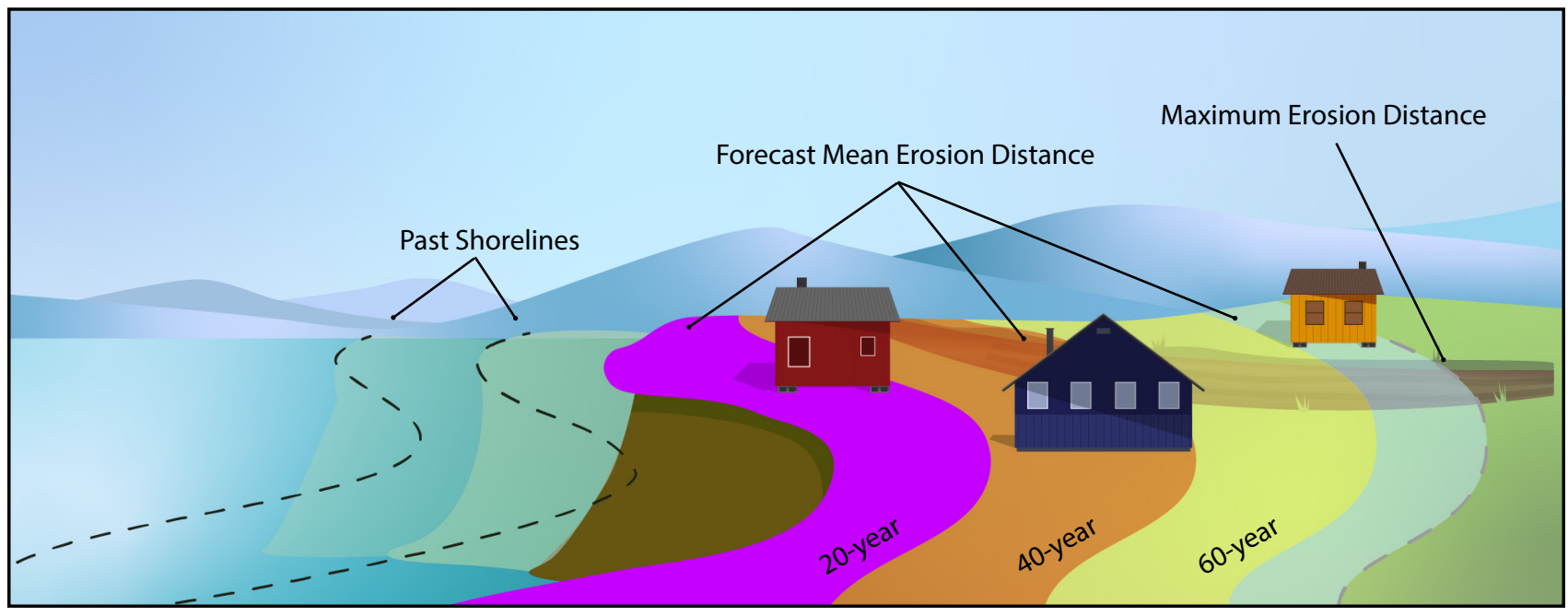

Figure 5. Diagram depicting linear erosion forecast method. Erosion of the shoreline is forecast to continue for 20,40 , and 60 years (purple, orange, and yellow, respectively). The light blue region represents the maximum forecast erosion in 60 years. In this example, the eroding shoreline is forecast to reach the red building within 20 years. The blue building is in the 40 -year erosion interval. The yellow building is just beyond the 60-year erosion forecast but still within the 60-year erosion uncertainty range (light blue).

percent confidence interval. Erosion exposure for other infrastructure such as roads and water lines is analyzed by computing the length of exposed infrastructure per 20-year interval.

Defining the forecast timespan is an important consideration. These erosion forecasts are intended to inform infrastructure planning. Erosion setback policies in the United States and building design lives are often made with 50-year timelines. Linear regression is a common method for defining coastal setback zones and erosion hazard areas across coastal zone management sectors (Perello, 2019). Most shoreline data available for Alaska communities date back to the 1950 s, approximately 60 years from the most recent shoreline data (201519). Crowell and others (1993) advise forecasts using 60 years of data not exceed 60 years into the future. With these considerations in mind, we forecast 60 years from the most recent shoreline (up to 6 years older than the publication date), so our products are relevant to the 50-year design and policy timeline for at least four years from the time of publication.

\section{Infrastructure Data and Erosion Exposure}

Databases of infrastructure are not complete or available for the entire state of Alaska (Larsen and others, 2008). For some rural communities, infrastructure was originally drawn by DCRA (2021). We update the layers first by converting file formats from AutoCAD to ArcGIS, then by using recent imagery to delineate relevant changes to the community, such as new or removed infrastructure.

To estimate erosion exposure, we compare erosion forecast extents to infrastructure outlines. This reveals what and how much infrastructure could be exposed to erosion in the future. We associate infrastructure with a cost of replacement in order to give more weight to items that may be more expensive to address (such as valuing a school more than a single residence). Cost of replacement is one of many methods to estimate exposure and does not completely quantify risk (see "Discussion" section; Crowell and others, 1999; Burgess and others, 2000; Larsen and others, 2008). 
Table 1. Generic cost of infrastructure in rural Alaska communities determined by the Alaska Native Tribal Health Consortium (ANTHC). Infrastructure listed include only those identified using community planning documents and aerial imagery. Units are linear foot (LF), square foot (SF), and lump sum (LS).

\begin{tabular}{|c|c|c|c|c|}
\hline Infrastructure & Unit & Unit Cost & $\begin{array}{l}\text { Minimum } \\
\text { Cost }\end{array}$ & Note \\
\hline Boardwalk & LF & $\$ 75$ & $\$ 75,000$ & \\
\hline Fuel Lines & LF & $\$ 60$ & $\$ 50,000$ & 2-inch schedule 40 steel pipeline \\
\hline Gravel Road & LF & $\$ 400$ & $\$ 200,000$ & Based on average of $\$ 2.1$ million per mile of road \\
\hline $\begin{array}{l}\text { Overhead Distribution } \\
\text { Lines }\end{array}$ & LF & $\$ 200$ & $\$ 50,000$ & Average distance between poles of 100 LF \\
\hline Water/Sewer Line & LF & $\$ 400$ & $\$ 50,000$ & \\
\hline Community Hall & SF & $\$ 1,000$ & $\$ 4,000,000$ & $\begin{array}{l}\text { Based on construction similar to the Mertarvik } \\
\text { Evacuation Center (multi-purpose building) }\end{array}$ \\
\hline Residential Housing & SF & $\$ 350$ & $\$ 400,000$ & $\begin{array}{l}\text { New construction of } 3 \text { - or 4-bedroom residence, } \\
\text { indoor plumbing, post and pad gravel foundation }\end{array}$ \\
\hline Unspecified Building & SF & $\$ 350$ & $\$ 400,000$ & $\begin{array}{l}\text { Only if greater than } 500 \text { SF; maximum cost of } \\
\$ 500,000\end{array}$ \\
\hline Airport & LS & $\$ 40,000,000^{*}$ & $\mathrm{~N} / \mathrm{A}$ & $\begin{array}{l}\text { Based on } \$ 10,000,000 \text { per } 1,000 \text { feet; will vary } \\
\text { based on gravel price }\end{array}$ \\
\hline Barge Landing & LS & $\$ 2,500,000^{*}$ & N/A & $\begin{array}{l}\text { Shallow draft landing with mooring points and small } \\
\text { laydown area }\end{array}$ \\
\hline Bulk Fuel Farm & LS & $\$ 4,500,000$ & N/A & 140,000 gallon capacity \\
\hline Church & LS & $\$ 500,000$ & $\mathrm{~N} / \mathrm{A}$ & $\begin{array}{l}\text { Large but simpler construction compared to } \\
\text { residential home }\end{array}$ \\
\hline City Office & LS & $\$ 500,000$ & N/A & Approximately equivalent to residential housing \\
\hline Clinic (medium size) & LS & $\$ 2,500,000$ & $\mathrm{~N} / \mathrm{A}$ & \\
\hline K-12 School & LS & $\$ 35,000,000$ & N/A & \\
\hline Landfill & LS & $\$ 1,000,000$ & N/A & \\
\hline Lift Station & LS & $\$ 1,000,000$ & $\mathrm{~N} / \mathrm{A}$ & \\
\hline Police and Jail & LS & $\$ 750,000$ & $\mathrm{~N} / \mathrm{A}$ & \\
\hline Power Plant & LS & $\$ 3,250,000$ & $\mathrm{~N} / \mathrm{A}$ & 3-generator module, 250 kW capacity \\
\hline Store & LS & $\$ 500,000$ & $\mathrm{~N} / \mathrm{A}$ & \\
\hline Teacher Housing & LS & $\$ 500,000$ & N/A & Duplex construction \\
\hline Tribal Office & LS & $\$ 500,000$ & $\mathrm{~N} / \mathrm{A}$ & Approximately equivalent to residential housing \\
\hline Wastewater Lagoon & LS & $\$ 6,000,000$ & N/A & 3 acres \\
\hline Water Storage Tank & LS & $\$ 1,500,000$ & N/A & 200,000 gallon tank on gravel pad \\
\hline
\end{tabular}

*Cost may be estimated using cost per SF or LF if appropriate. 
Unit costs for replacement are assigned to each type of infrastructure (table 1). If available, we use reported infrastructure cost from community plans, such as local hazard mitigation plans. A consistent cost is applied to each community using generic estimates (table 1) developed using the professional judgment of Alaska Native Tribal Health Consortium (ANTHC) engineers, consultants, and partner agencies. Unit costs are approximate order of magnitude estimates intended to represent an average cost for infrastructure construction in rural Alaska. The costs developed by this method are based on average costs in northern and western Alaska and are similar to those found in community hazard mitigation plans (such as Nunam Iqua, Quinhagak, and Napakiak) available at www.commerce.alaska.gov. Assumptions used to determine costs are found in table 1. Uncertainty of each replacement cost is estimated to be \pm 30 percent.

We do not make any adjustments or assumptions for regional variances, population scaling, cost-sharing, or adaptation options such as retreat, accommodation, decommissioning, environmental restoration, building shore protection, or modifying existing infrastructure. These cost estimates are a snapshot in time-we do not consider any changes in the cost of infrastructure over time or maintenance of existing infrastructure. These calculations are intended to give community decision makers the capacity to identify priority areas or facilities within a community that may require a response, mitigation action, or adaptation strategy. These calculations are not meant to serve as construction estimates or an economic assessment of risk.

The estimated cost to replace infrastructure depends on the type of infrastructure. If erosion can compromise the entire facility or feature, a lump sum (LS) cost is used. This is the case for buildings, fuel and water tanks, landfills, and wastewater lagoons. Larger residences generally cost more than smaller ones, so we estimate residential cost using square footage (SF). The cost to replace airport runways is computed using linear footage (LF) because they are sometimes repaired rather than abandoned. For example, if a gravel runway costs $\$ 40,000,000$ and is 4,000 feet long, the runway cost is $\$ 10,000$ per linear foot. A 60 -year erosion forecast of 50 feet of runway will likely not cause an abandonment; instead, it will cost $\$ 500,000$ to rebuild the eroded section (or replace it by building on the other end of the runway). Similarly, linear features such as roads, boardwalks, power lines, water utility corridors, and fuel lines may not require complete replacement if a small section is damaged by erosion, so cost is measured using the linear foot of the feature centerline.

Alternatively, erosion can compromise infrastructure to a greater extent even when only one section is at risk. For example, if a small section of water pipe is exposed, then the remaining structure may need rerouting. Given the labor and equipment costs to complete even a small project, a minimum cost associated with building or repairing infrastructure is applied to infrastructure with unit costs. Additionally, small buildings and residential housing may be replaced with modern structures that, in practice, are found to have a minimum cost of replacement regardless of the size of the original building. Generic unit and minimum costs are listed in table 1.

\section{Special Cases}

We forecast erosion exposure for communities on tidally influenced rivers, but some river systems are too complex for linear forecasts. The forecast method is practicable for rivers that have exhibited nearlinear changes over the study period (see Napakiak). Linear forecasts are less appropriate for rivers with erosion at sharp bends because they may experience avulsion and subsequent channel migration (Hooke, 2007; see Quinhagak). Forecasts in complex river systems require greater effort than the scope of this project (Lagasse and others, 2002), so we use alternative methods to communicate erosion exposure. The simplest method is to visualize river change with footprints of past rivers so decision-makers can see changes and make their own interpretations (fig. 6). 
Many communities have characteristics that limit the ability to forecast erosion with the methods outlined in this report. Some have slow erosion rates, stable shorelines, or exhibit accretion trends, so the forecast shows no major changes. In these cases, we decide not to create a map but note findings in the community summary. For communities with erosion mitigation structures (such as a seawall), we do not forecast for the locations where protections exist. We cannot assume the effectiveness and longevity of the erosion control measures, so the 60-year uncertainty polygon is mapped as a "worst-case scenario" visual aid. Decision makers can use nearby forecasts, uncertainty, and historical shoreline positions to interpret the effectiveness of existing erosion control measures.

\section{DISCUSSION OF METHODS}

\section{Advantages and Limitations of Linear Regression Erosion Forecasts}

Linear regression analysis is the simplest method of forecasting; the results are easy to understand, as are the limitations (Crowell and others, 2018). However, linear forecasts are not appropriate for coastlines with highly episodic erosion drivers or complex multi-forcing factors (Douglas and Crowell, 2000). For example, rocky cliffs can experience extremely episodic erosion in the form of rockfalls (Hapke and Plant, 2010), and may be better represented by a hazard rating (Dunham and others, 2017). Mass wasting event cycles-which can be triggered by erosion undercutting a slope or by seismic activity - can take decades or centuries to repeat, requiring greater analysis to identify risk (Burns and Mickelson, 2016). Rivers can also undergo erosion in relatively unpredictable episodes and may require non-linear risk assessments (Lagasse and others, 2002; fig. 7). Gradual erosion can be forecast until a significant event, such as avulsion, changes the entire river morphology (Hooke, 2007). The event can be triggered by either gradual erosion or a sudden increase in discharge (due to rainfall, snowmelt, and/or flooding), so the exact timing is challenging to forecast (Turnipseed and
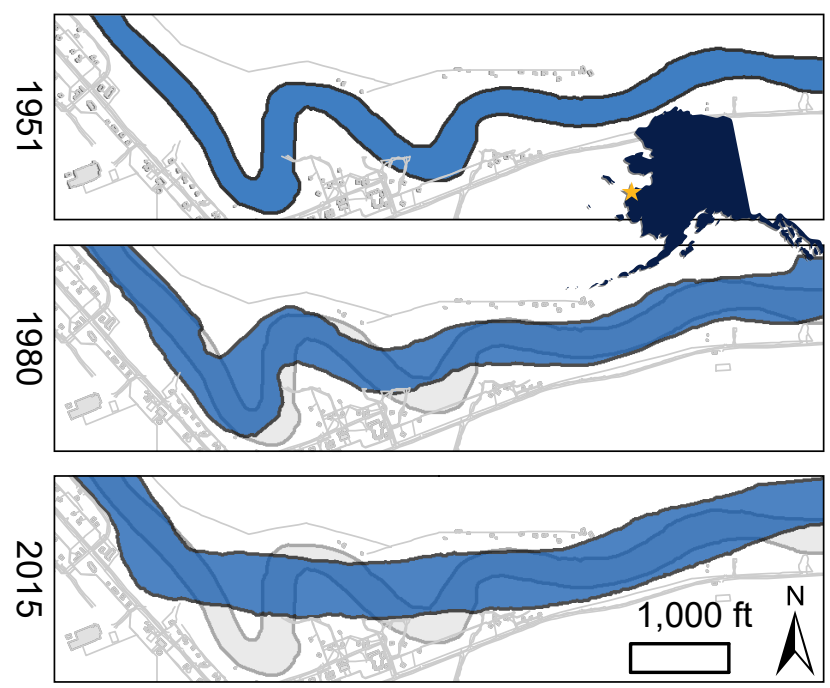

Figure 6. The history of the Alakanuk River (blue) is shown with the 1951 river footprint (gray area). The 2015 infrastructure (light gray lines) is shown in all panels. The river doubled in width and lost meanders over 64 years. Some infrastructure is built in abandoned river meanders. A traditional erosion forecast is not suitable, but the past river footprints communicate the dynamic history and susceptibility to change.

others, 2021). There are many river communities in Alaska with erosion hazards where linear forecasts may not sufficiently identify risk (UAF and others, 2019). Beyond natural forcing, erosion can also be increased by anthropogenic activity such as boat wake, vehicles scouring sand on beaches and dunes, and vegetation and permafrost degradation from frequent traffic or construction. Similarly, erosion protection structures and beach nourishment may mitigate or offset the natural or induced erosion. Computed erosion rates represent the summation of all forcing factors, and linear forecasts imply those factors will continue at the same historical rate, so users should apply critical judgment and local knowledge to interpret results.

Expertise and local knowledge are instrumental in critically evaluating the results of linear erosion forecasts. For example, even if a coastline has experienced steady erosion, the rate can change significantly when erosion reaches different topography or lithology. This is occurring in Dillingham, where rapid and consistent erosion of a peat meadow is encroaching on the wastewater lagoon (fig. 8). The 

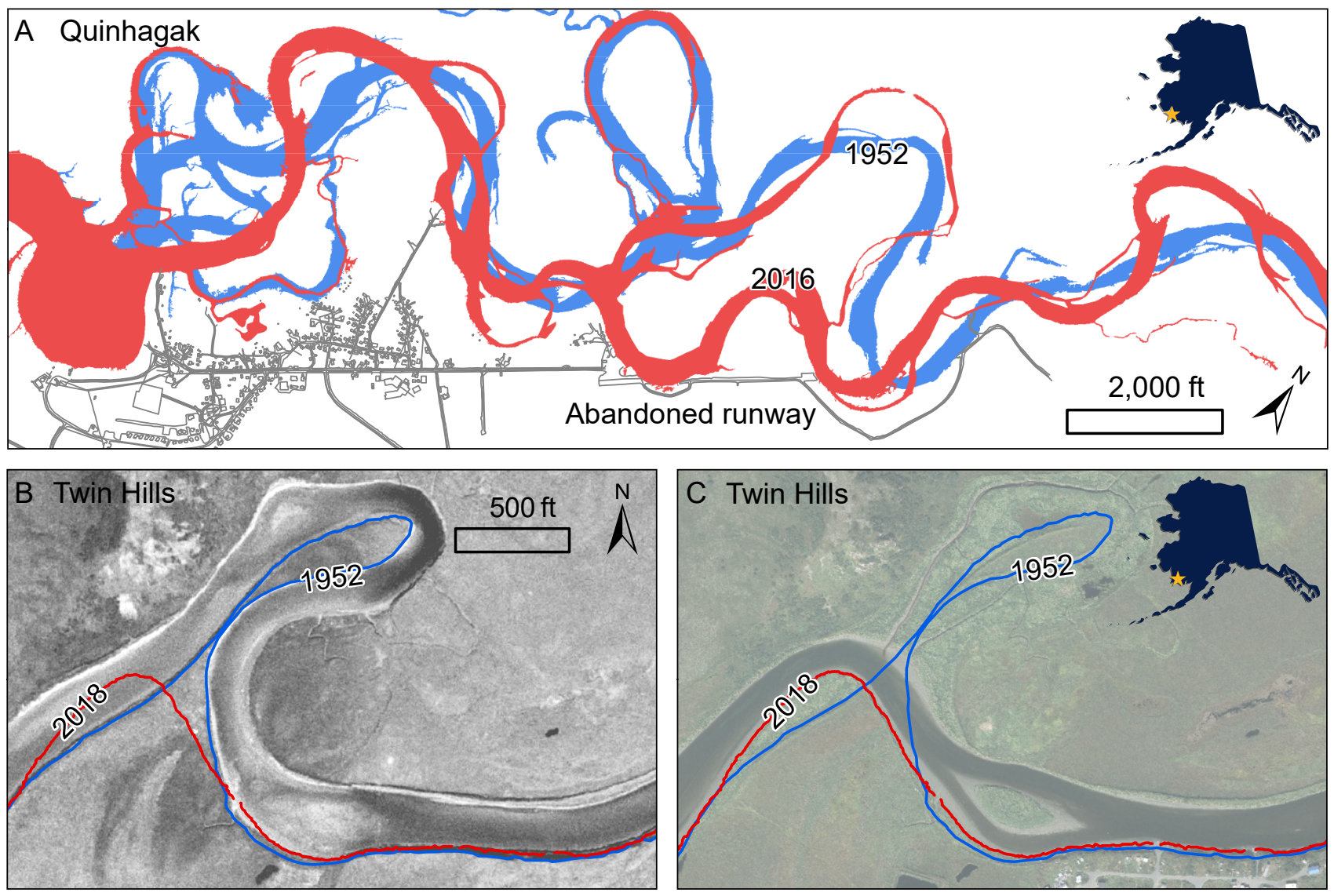

Figure 7. Examples of river shoreline change at the communities of Quinhagak and Twin Hills show how rivers can erode ununpredictably. A. The Kanektok River switched channels thousands of feet between 1952 (blue) and 2016 (red) and eroded the now-abandoned runway in Quinhagak. Linear regression could not have forecast this change. B. The Twin Hills River gradually eroded the thin strip of land in 1952 (blue). C. After breaking through this barrier, the river rerouted to its modern position (red). Although the river was significantly modified, shoreline change rates remained relatively stable near the community. These two examples demonstrate the drastic contrast between impacts that river change can cause, emphasizing the importance of using appropriate hazard assessment methods.

linear erosion forecast shows the shoreline will reach the lagoon around 2058. However, the peat meadow transitions into a vegetated hill covered with fill from the lagoon's construction. This change may significantly alter the rate of erosion, so a closer investigation (such as a geotechnical engineering study) would be appropriate to assess exposure. In communities with similar situations, the maps and reporting from this assessment can be used to demonstrate potential exposure and justify the need for in-depth hazard studies. This scenario is uncommon across the communities in this study and discussed when applicable in the community-specific reports.

The fundamental assumption of linear regression erosion forecasts is erosion rates will not accel- erate or slow over time. Periods of greater or lesser erosion rates are expected but thought to remain within a confidence interval. This assumption is challenged by the expectation that coastal erosion will accelerate in response to longer ice-free water seasons, warmer temperatures, and many other climate-related factors changing in Alaska and the Arctic (Chapin and others, 2014). The mechanistic connection between these factors and erosion is generally understood, but the exact magnitude of acceleration is not well defined. For example, Jones and others (2018) measure erosion rates accelerating up to 2.5 times the historical rate on Alaska's north coast, but conclude there is no single driver or combination of drivers to completely explain the observed change. 

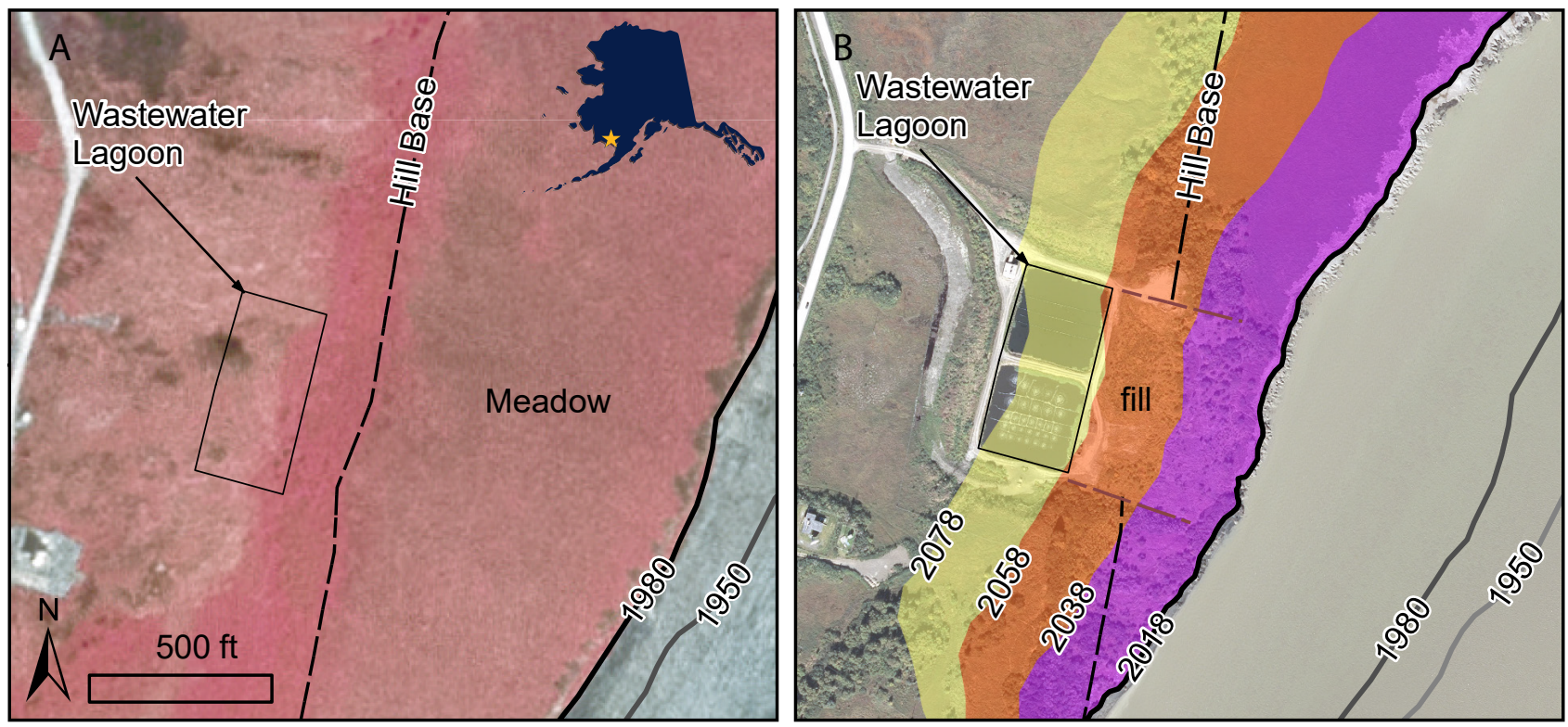

Figure 8. The Dillingham wastewater lagoon is an example of how linear shoreline forecasts may be inaccurate when there are changes in topography or lithology that likely change the erosion rate. (A) The 1980 color-infrared image shows the hill where the Dillingham wastewater lagoon is eventually built, and the broad meadow downslope toward the shoreline. (B) The wastewater lagoon is built into the hill, and fill from construction is deposited seaward. Erosion continues at a linear rate toward the hill's base and the fill area, suggesting an impact date near 2058; however, the fill area has a different lithology and vegetation cover that can significantly change erosion rates.

On Chukchi Sea coastlines, Farquharson and others (2018) observe increased dynamism (erosion and accretion) that may be a symptom of an increase in climate-driven forcing factors, but do not explicitly find accelerated shoreline erosion. Instead, a trend of increasing disturbance factors (such as storms during open water) do not allow coastal systems adequate time to equilibrate, possibly leading to a major shift in coastal geomorphology (Farquharson and others, 2018). These examples illustrate the complex combination of erosion drivers and coastal response that hinders attempts to introduce a simple acceleration variable into an otherwise linear forecast.

Irrgang and others (2019) explore whether shoreline datasets like those used in our study are adequate to detect and forecast acceleration or deceleration of erosion. In the most extreme example, their exponential model forecasts erosion rates increasing by more than three times, on average, as compared to the linear rate. Such increases are rare for coastlines that are already rapidly eroding. This may be due to a lack of increasing erosion drivers. For example, where thawing permafrost leads to increased erosion rates, the rates may stop increasing once the ground has thawed completely. In addition, once storm seasons are ice free and 100 percent of wave events are unimpeded, there can be no greater increase in this major forcing factor (sea ice loss) to further accelerate erosion rates. Regions of Alaska where these drivers have peaked may have already undergone their transition to faster or more dynamic erosion rates and will instead see constant or even decelerated rates, what Farquharson and others (2018) call a "new state of geomorphic equilibria.” In such cases, a linear forecast based on historical or recent shoreline change is more appropriate than an acceleration model. The limited number of shoreline vector years in Alaska already inhibits complex forecast methods (Crowell and others, 1997; Douglas and Crowell, 2000; Genz and others, 2007). The discussed studies demonstrate how limitations of the current shoreline data and understanding of the role of climate-forcing parameters prohibit the ability to 
forecast non-linear changes. While linear forecasts may underestimate erosion rates that are accelerating, they remain the most reliable method for widespread use (Crowell and others, 2018).

Parameterized and numerical models can incorporate accelerated erosion drivers in forecasts. For example, where sea level rise is the main driver of shoreline migration, the rising MHW datum can be mapped on an elevation model to forecast future shorelines (Crowell and others, 1997). However, sea level rise is difficult to estimate in Alaska due to limited water level and land level change data (Gorokhovich and Leiserowiz, 2012; Overbeck, 2018; DeGrandpre and Freymueller, 2019). Bull and others (2020) demonstrate the combination of environmental parameters required to model and possibly forecast permafrost erosion. Coastal permafrost erosion acceleration is primarily driven by the interaction between rising temperatures and reduced sea ice (Lantuit and others, 2013; Jones and others, 2018). A longer open water season allows increased thermal denudation and net wave energy, as well as more time for storm-driven waves to act on the coast (Overeem and others, 2011; Farquharson and others, 2018; Bogardus and others, 2020). Given that warming is projected to continue (Intergovernmental Panel on Climate
Change, 2014; Thoman and Walsh, 2019), parameterized and numerical models can incorporate climate scenarios to forecast non-linear change. The necessary baseline data to accomplish this effort are largely absent for Alaska (Bull and others, 2020). Ultimately, advanced models will require the extensive collection of baseline data, such as relative sea level rise measurements, wave climatology data, a densified water level observation network, tidal-to-geodetic transformation tools (such as VDatum) to connect nearshore bathymetry to bare earth elevation models, permafrost and lithology characteristics, and climate models projecting environmental change. Erosion is a time-sensitive issue, and communities are already making decisions that will define their erosion response for the coming decades. Given these needs and constraints, a simple linear regression analysis remains an excellent first-order method to estimate erosion exposure across most communities in Alaska.

Linear regression analysis assumes erosion will continue at the same rate as it has been measured historically. For many sites, shore protection measures have been placed or constructed to mitigate or halt erosion. For example, rock revetments in Shishmaref reduced erosion rates, but erosion continues in the unprotected areas (fig. 9). We do

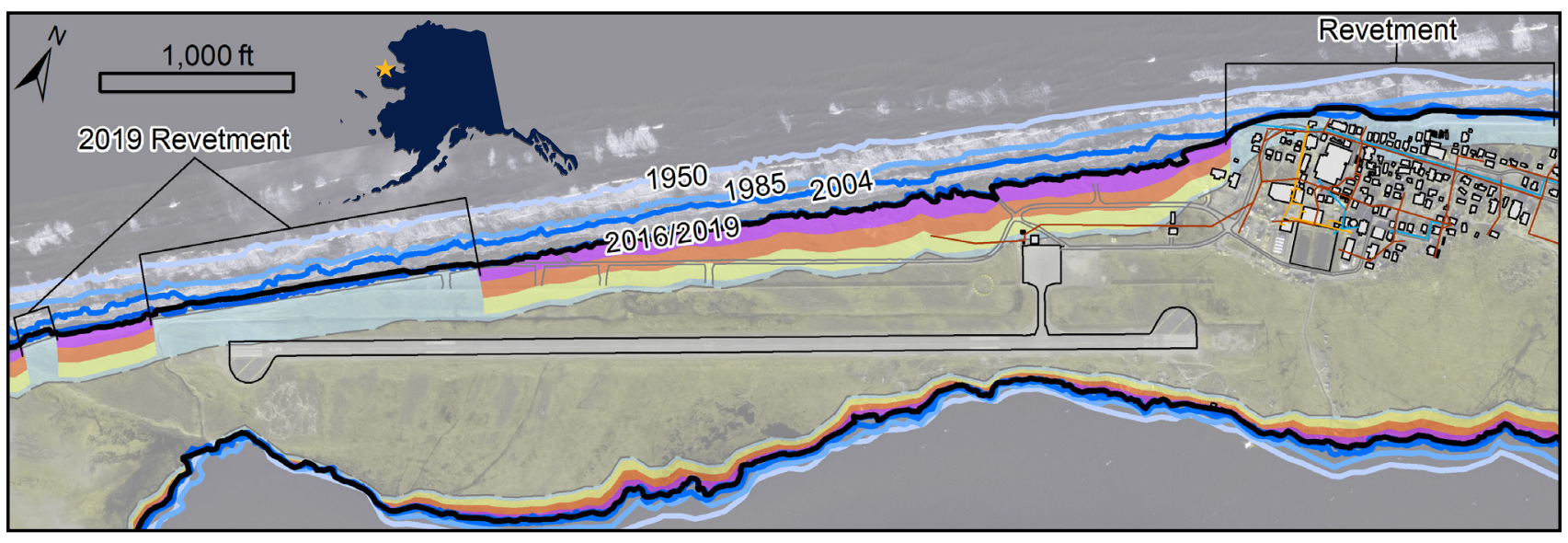

Figure 9. The shoreline history of Shishmaref (blue-scale lines) shows erosion across the island and stability at the eastern revetment between 2004 and 2019. The erosion forecast is only made where revetments do not exist, but the extent of the 60 -year forecast uncertainty (light blue) is kept to approximate where erosion would occur based on past shoreline positions. Without the 2019 revetment, erosion is forecast to impact the runway. The revetment fronting the community protects almost all coastal infrastructure in this figure. 
not display erosion forecasts along revetments or other shore protection structures; instead, we map the uncertainty boundary in order to communicate the possible magnitude of erosion based on past changes. The forecast does not account for edge effects around shoreline protection. As more coastal modifications are made, linear forecasts based on past shorelines alone become impossible. This is the case for Shaktoolik, where a community-wide berm is eroded and repaired frequently. These examples demonstrate the range of limitations caused by management of coastal sediment and placement of erosion control structures.

\section{Infrastructure and Replacement Cost}

Infrastructure location and replacement cost are important aspects of exposure assessments because they help quantify the magnitude of exposure that erosion poses, but there are limitations in these datasets as well. Maintaining an accurate inventory of infrastructure is challenging, however updates to the infrastructure databases are based on the most recent aerial imagery, community planning documents, and fieldwork observations by DGGS. Communities are constantly changingespecially those with rapid erosion rates-so some infrastructure data may already be outdated. This was the case in Napakiak, where at least five structures were removed between 2015 and 2019 (the most recent aerial and satellite imagery we acquired, respectively; fig. 1). In addition, our method does not estimate the success, longevity, or upkeep costs of engineered solutions.

Infrastructure replacement cost is the cost of construction and does not include the total cost a project may entail or any cost adjustments over time. The infrastructure metadata lack critical details needed for an economic analysis of erosion exposure, including the useful life, age, and maintenance costs of infrastructure (Larsen and others, 2008). Replacement and demolition can also be an expensive process, especially for infrastructure with environmental contaminants, such as a fuel tank farm. Infrastructure construction and dismantling costs also increase if the community does not have the existing capacity to perform these projects (such as heavy equipment, tools, and personnel), or if projects need to be accomplished in phases over an extended period due to weather or funding availability. Access to resources like gravel or armor rock can substantially change the cost of projects due to shipping. Ultimately, the replacement costs estimated in this analysis are meant to provide enough information for community leaders to prioritize what infrastructure must be replaced and when; they do not reflect the total project cost.

\section{Subsistence and Cultural Sites}

Most of the communities assessed have subsistence-based economies: fishing, hunting, and harvesting. Erosion can cause significant damage to fish camps, cut off access to hunting grounds, or destroy safe harbors and launch points for fishing vessels (Brady and Leichenko, 2020; Overbeck and others, 2020). The reduction or loss of critical subsistence activities can bring community-wide disruptions. Alaska's communities are also home to Indigenous people whose ancestors have lived along the coast for thousands of years at sites outside community footprints (Mason and others, 2012). These sites and landmarks are not consistently well-documented, although some have been found near eroding shorelines. Incorporating subsistence and cultural impacts is beyond the scope of what can be achieved by this assessment. Communities and organizations must leverage local knowledge along with scientific studies to evaluate erosion impacts to subsistence and cultural resources.

\section{RESULTS}

Results of this assessment are documented in community-specific summary reports. Two types of map products provide a visual presentation of erosion forecasts near infrastructure (fig. 10). There may be more or fewer maps per location depending on the extent and severity of erosion. 


\section{Erosion Forecast Map}

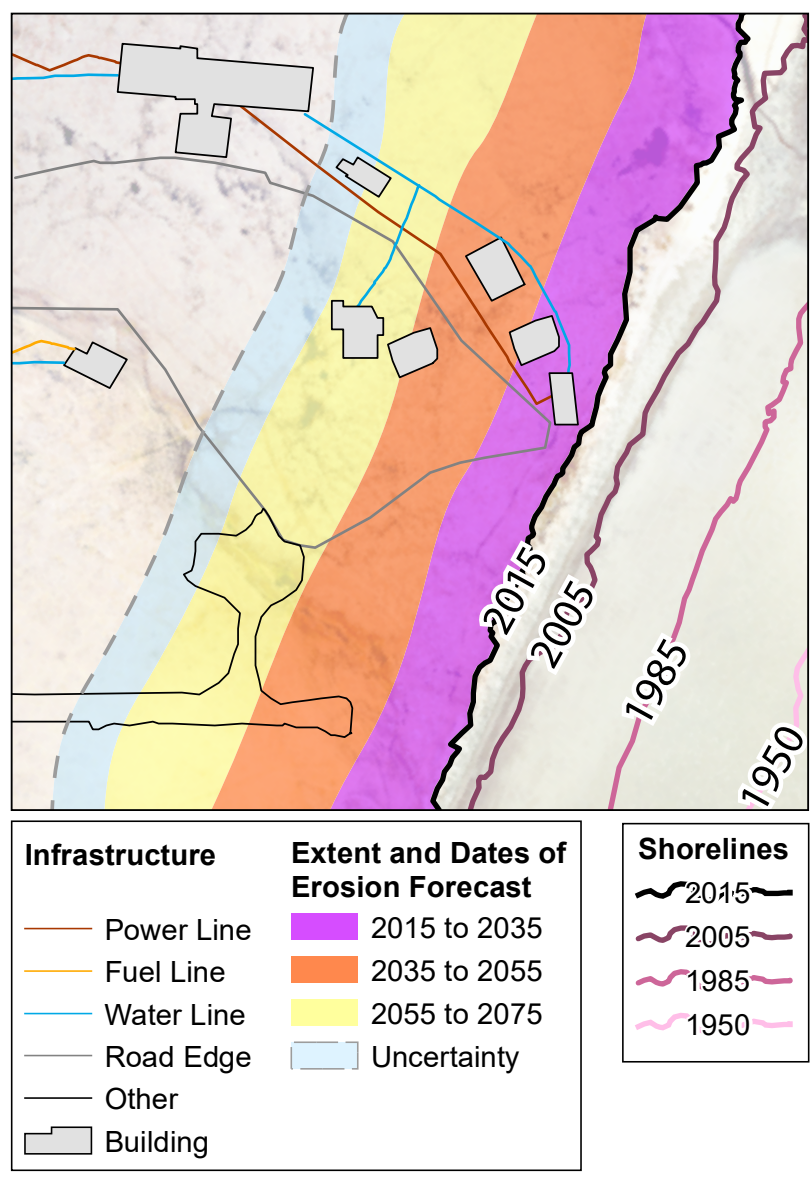

\section{Erosion Exposure Map}

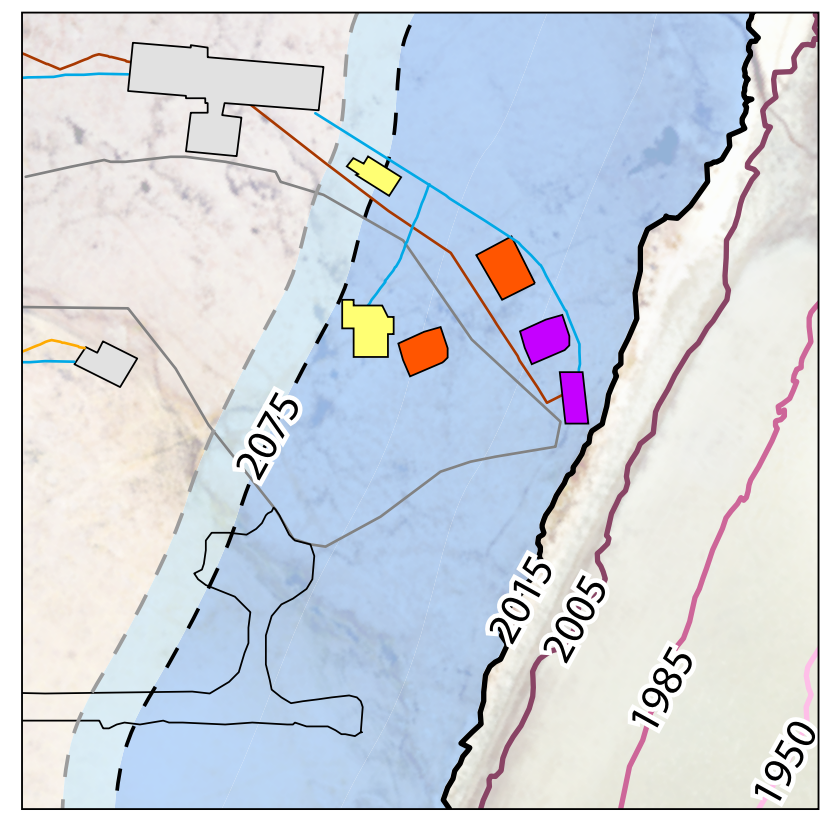

Infrastructure

Buildings and Dates Extent and Date of in Erosion Forecast Erosion Forecast

Power Line

Fuel Line

Water Line

Road Edge

Other
ए 2015 to 2035

$\square 2035$ to 2055

$\square 2055$ to 2075

$\square>2075$

Figure 10. Examples of map products. Erosion Forecast Maps (left) show the extent of forecast erosion over time. Erosion Exposure Maps (right) show the total extent of erosion over 60 years and highlight infrastructure impacts per 20-year interval. Both maps show infrastructure categories, 60-year uncertainty, and historical shoreline positions.

The Erosion Forecast Map shows where future shorelines are forecast to be in 20-year intervals (fig. 10). The map displays the timing and extent of erosion relative to infrastructure locations. Exposure of undeveloped areas can also be determined. Past shorelines are included.

The Erosion Exposure Map shows which buildings are within the erosion forecast zone (fig. 10 ). We scale this map to focus on exposed buildings, which are colored by 20 -year intervals. The 60-year extent of erosion is shown (darker blue), along with uncertainty (lighter blue) and past shorelines (pink scale).

Of the 48 communities assessed, 33 have infrastructure in areas forecast to erode by the 2070s. Of the remaining 15 communities, many experience erosion; however, we cannot forecast exposure due to the nature of erosion and recovery processes and/or local coastal management practices such as renourishment after coastal storms or stabilization of the coastline. Results are shown in figure 11 as a grouped percentage of the total replacement cost of all communities assessed, ordered by individual cost. Newtok and Napakiak comprise nearly 50 percent of the total cost. Thirteen more communities comprise another 40 percent (meaning their combined cost is nearly equal to Newtok and Napakiak combined). The 17 Yukon-Kuskokwim Delta communities assessed comprise 82 percent of the total cost. More than 40 percent of the estimated cost is forecast to occur 


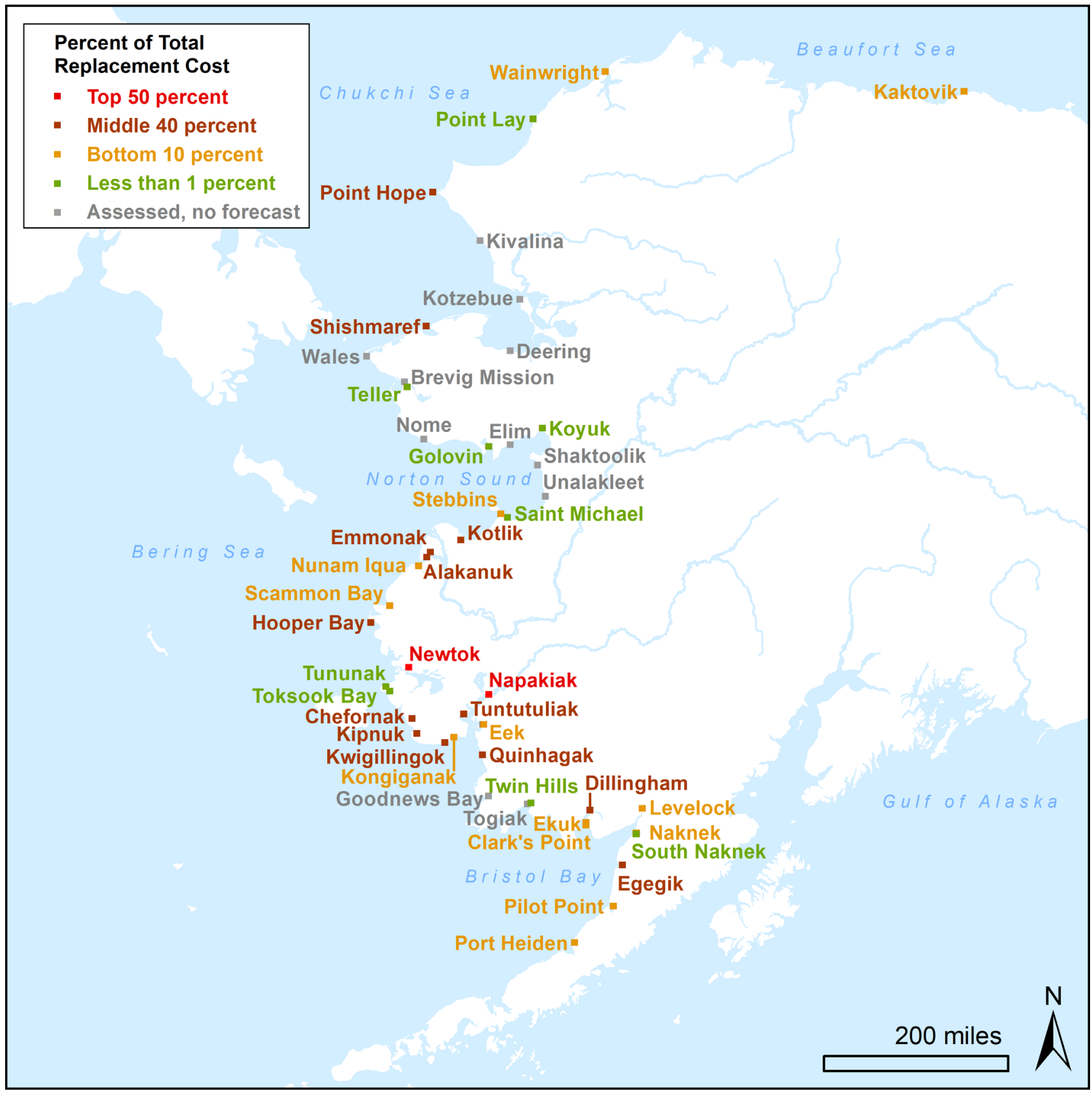

Figure 11. Percent of total replacement cost of infrastructure forecast to be exposed to erosion by the 2070 s for each of the 48 communities assessed. The greatest costs are found on the Yukon-Kuskokwim Delta.

before 2040. Buildings comprise 69 percent of the total cost. Erosion is forecast to reach 4 wastewater lagoons, 7 airports, 10 barge landings, and 3 landfills. Appendix A lists infrastructure exposure per community. See community-specific reports for more information.

\section{DISCUSSION OF RESULTS}

This assessment identifies infrastructure that could be exposed to erosion if historical shoreline retreat continues at its long-term rate and is not mitigated. The practice of forecasting, in general, has caveats stemming from data generation, analysis 
methodology, and the presence of uncontrolled variables. Two of the greatest variables - climate change and coastal management practices-will reduce forecast accuracy, especially further into the future. This assessment provides a snapshot of erosion exposure based on known erosion trends. Continued monitoring of erosion rates and collection of new aerial imagery at 5- to 10-year intervals is critical to keep adequate accounting of erosion exposure.

\section{Intended Use of Erosion Exposure Assessments}

This erosion exposure assessment identifies the location and replacement cost of infrastructure in areas forecast to erode by the 2070s. This provides one component to be included in a larger assessment of hazards, such as a local or regional multi-hazard assessment or mitigation plan. When assessing erosion risk for a particular community, one must also consider the magnitude of the hazard and vulnerability (Crichton, 1999). Because erosion results in the permanent loss of developable land, solutions tend to be limited to prevention or relocation: erosion hazards are reduced through mitigation, and exposure is reduced by relocating infrastructure out of the forecast erosion area. The vulnerability of the community to erosion is related to these concepts but also accounts for critical facilities, vulnerable populations, and broader economic or intangible impacts. For example, if erosion of the only power plant will cut off power for the entire community, they are likely more vulnerable than a place with several homes but no critical infrastructure in an erosion area. Residents who do not have the means to relocate are also more vulnerable. Additionally, erosion of the boat parking and launching area will disproportionately impact a subsistence fishing economy. These considerations must be made by the risk assessor, in addition to the exposure component.

Erosion forecasts are useful for defining timetables to address hazards and identify safe locations. In Newtok, erosion is rapid, and there is no significant shoreline protection. The community is relocating to the new site of Mertarvik, a challenging endeavor that has taken decades and is still not complete. During this lengthy transition period, critical infrastructure must be replaced to maintain vital utilities such as electricity, heat, and clean water. However, the community struggled to obtain funding for running water and wastewater infrastructure at Newtok due to the threat of erosion and inevitable relocation, resulting in health issues (Bronen and Chapin, 2013). Our erosion forecast shows that the wastewater lagoon, washeteria, health clinic, airport runway, school, and numerous homes and other structures may erode by 2035 (see Newtok). USACE (2008) forecasts similar impacts culminating by 2027 . While the results are bleak, they also identify areas not exposed to erosion, giving the community more leverage to replace critical infrastructure by demonstrating safe areas and timelines.

\section{Consequences of Unclear and Exaggerated Erosion Forecast Language}

Shishmaref, Kivalina, and many more Alaska communities are discussed in media as if they will experience the same erosion future as Newtok (Herrmann, 2017). Shishmaref has a history of rapid erosion and major impacts, but Mason and others (2012) find that many sources grossly embellish erosion impacts. The greatest exaggeration came in 1975 from an engineering firm that speculated up to half of the community eroding between 1976 and 1985. Based on projections from computed shoreline change by Mason and others (2012), the impact purported by the engineering firm could have occurred within 30 years, not 1 to 10 years. While the erosion exposure is significant, the exaggerated erosion forecast led to rushed mitigation strategies that largely failed (Mason and others, 2012). Shishmaref's current revetment is significantly more effective at halting erosion, and long-term erosion rates suggest most of the community may be safe for several decades (fig. 9). Although the realized erosion was far less than the 
exaggerated forecast and mitigation has successfully halted erosion in front of the community, Shishmaref's vote to relocate barred the community from constructing running water and piped sewer infrastructure (Bronen and Chapin, 2013).

Kivalina's experience with erosion hazard response is similar to Shishmaref's, despite having a combination of erosion and accretion that nets into a stable shoreline (USACE, 2009b). Two major storms (2004 and 2005) caused an unprecedented 70 to $80 \mathrm{ft}$ of erosion. Despite the known historical stability, USACE (2009b) assumes this erosion will continue annually, and claims, "...infrastructure costs in Kivalina total more than $\$ 105$ million for the 20 -year project horizon, although the community will become uninhabited long before complete loss occurs." The assumed accelerated erosion may stem from an outdated storm surge model that predicted the 2004 storm was a 1 -year event and the entire community could be inundated by a 5-year event, even though no community-inundating storm has been observed in over 100 years (Glenn Gray and Associates, 2010). Like Shishmaref, Kivalina struggled to obtain funds for adequate sewer and water systems because any new infrastructure would purportedly be built in a floodplain, eroded, or abandoned after the community voted to relocate (ANTHC, 2011; Bronen and Chapin, 2013). Chapman and others (2009) published a storm surge model that estimates substantially lower flood levels, showing that even a 100-year storm would barely reach coastal infrastructure and certainly would not inundate the barrier island (Glenn Gray and Associates, 2010). While hindsight indicates the USACE (2009b) erosion forecast was inaccurate, there is probable reason to believe erosion will increase due to reduced sea ice during storm seasons (Fang and others, 2018; Farquharson and others, 2018). Fortunately, the rock revetment built in 2010 appears to have prevented further bluff erosion for that section of the spit, and the beach is accreting (Overbeck and others, 2020).

Shishmaref, Kivalina, and likely many other communities are in a gray area where erosion hazards are present and possibly increasing but magnitude of exposure is often exaggerated. For these two communities, hazards are mostly addressed through adequate mitigation, yet media and reports continue to echo the language predicting imminent community-wide destruction (Herrmann, 2017; Mason and others, 2012). These echoes disempower communities by ignoring their resilience efforts (Herrmann, 2017), and lead to serious damage to societal health, such as lack of access to safe water (Bronen and Chapin, 2013). These examples emphasize the importance of incorporating uncertainty, scientific judgment, and local observations when using erosion forecast maps.

\section{Future Work}

This assessment is the first attempt to quantify erosion exposure for several Alaska communities. There are many limitations to the results, stemming from data availability, analysis methods, and evaluating impact through estimates of replacement cost. Future work should address these limitations. Updated infrastructure data layers are vital to reflect the current community layout. Given the prominent subsistence economy, erosion costs should be expanded to include subsistence-related resources and assets. Cultural sites were also not included in this analysis because no consistent database of their locations was available. Possible follow-on work could also examine more nuanced vulnerability factors that incorporate environmental, cultural, and socio-economic data. We recognize that shoreline erosion forecasts are not suitable for communities with primarily beach (not bluff) erosion or complex river systems, so a separate analysis method is needed to adequately assess erosion exposure. Finally, our assessment will become outdated as communities and the environment change. Many locations saw major infrastructure and shoreline change in the approximately 10 years between the USACE (2009a) assessment and our study. We suggest the methods of this study-improved to include more communities and assets-be repeated within 10 years. These assessments can be incorporated into 
the 5-year hazard mitigation plan updates common to most communities.

\section{CONCLUSION}

We forecast erosion based on a linear shoreline change in rural Alaska communities. Resulting products communicate erosion exposure: the timing and extent of erosion and how it relates to existing infrastructure. The community-specific erosion exposure assessments include maps and tables displaying the extent of the erosion forecast, historical shorelines, and existing infrastructure outlines to illustrate local erosion hotspots and the relative magnitude of impact based on estimated replacement costs of infrastructure. Communities can incorporate this assessment into local hazard mitigation plans and applications for funding, when advising new construction, or sharing their experiences. Linear erosion forecasts are not sufficient where there is significant coastal management through coastal protections or shoreline nourishment. We do not forecast erosion for these coastlines. Instead, we recommend regular re-mapping and monitoring of coastal elevations, as well as considering parameterized or numerical models. Erosion is a pervasive issue across Alaska, and continued warming and concomitant changes will only exacerbate the problem. Erosion forecast tools provide a baseline expectation of exposure, but there will always be limitations. Communities and other users must combine these tools with local knowledge and evidence to decide the best course of action.

\section{ACKNOWLEDGMENTS}

This work was funded by the Denali Commission Village Infrastructure Protection Program through the project "Systematic approach to assessing the vulnerability of Alaska's coastal infrastructure to erosion." We gratefully thank Dr. Nicole Kinsman of the National Oceanic and Atmospheric Administration and Dr. Craig Tweedie of the University of Texas at El Paso for their thorough peer reviews of this report. 


\section{REFERENCES}

Alaska Division of Community \& Regional Affairs (DCRA), 1982, A listing of Alaskan communities for documentation of erosion problems: $\mathrm{Di}$ vision of Community Planning, 18 p.

2021, DCRA community profile maps: [website] found at: https://dcced.maps.arcgis.com/apps/webappviewer/index.html? id=18fdb060875740fdad22099ca779d637

Alaska Division of Homeland Security \& Emergency Management (DHS\&EM), 2018, State of Alaska hazard mitigation plan: DHS\&EM, 753 p.

Alaska Native Tribal Health Consortium (ANTHC), 2011, Climate change in Kivalina, Alaska: ANTHC Center for Climate and Health, 66 p.

Boak, E.H., and Turner, I.L., 2005, Shoreline definition and detection-A review: Journal of Coastal Research, v. 21, no. 4, p. 688-703.

Bogardus, Reyce, Maio, C.V., Mason, O.K., Buzard, R.M., Mahoney, A.R., and de Wit, Cary, 2020, Mid-winter breakout of landfast sea ice and major storm leads to significant ice push event along Chukchi Sea coastline: Frontiers in Earth Science, v. 8, no. 344, 18 p. http://doi. org/10.3389/feart.2020.00344

Brady, M.B., and Leichenko, Robin, 2020, The impacts of coastal erosion on Alaska's North Slope communities-A co-production assessment of land use damages and risks: Polar Geography, v. 43, no. 4, p. 259-279.

Bronen, Robin, and Chapin, F.S., III, 2013, Adaptive governance and institutional strategies for climate-induced community relocations in Alaska: Proceedings of the National Academy of Sciences, v. 110, no. 23, p. 9,320-9,325.

Bull, D.L., Bristol, E.M., Brown, Eloise, Choens, R.C., Connolly, C.T., Flanary, Christopher, Frederick, J.M., Jones, B.M., Jones, C.A., Ward Jones, Melissa, Kasper, J.L., McClelland, J.W., Mota, Alejandro, and Tezaur, Irina, 2020, Arctic coastal erosion-Modeling and experimentation: SAND2020-10223, Sandia National Laboratories, NM, 229 p.

Burgess, Kevin, Samuels, Paul, Chatterton, John, Penning-Rowsell, E., and Deakin, Robert, 2000,
Assessment of economic value of national assets at risk from flooding and coastal erosion, in Annual Conference of River and Coastal Engineering, University of Keele, 2000, MAFF, London, 10 p. Burns, W.J., and Mickelson, K.A., 2016, Protocol for deep landslide susceptibility mapping: Oregon Department of Geology and Mineral Industries Special Paper 48, 66 p.

Chapin, F.S., III, Trainor, S.F., Cochran, P., Huntington, H., Markon, C., McCammon, M., McGuire, A.D., and Serreze, M., 2014, Ch. 22-Alaska, in Melillo, J.M., Richmond, T.C., and Yohe, G.W., eds., Climate change impacts in the United States - the third national climate assessment: U.S. Global Change Research Program, p. 514-536.

Chapman, R.S., Kim, S.-C., and Mark, D.J., 2009, Storm-induced water level prediction study for the western coast of Alaska: U.S. Army Corps of Engineers Coastal and Hydraulics Laboratory, $92 \mathrm{p}$.

City of Kivalina, 2015, City of Kivalina hazard mitigation plan-updated December 2015: The City of Kivalina Hazard Mitigation Planning Team, 275 p.

Crichton, David, 1999, The Risk Triangle, in Ingleton, J., ed., Natural Disaster Management: Leicester, England, Tudor Rose, p. 102-103.

Crowell, Mark, Douglas, B.C., and Leatherman, S.P., 1997, On forecasting future U.S. shoreline positions-A test of algorithms: Journal of Coastal Research, v. 13, no. 4, p. 1,245-1,255.

Crowell, Mark, Leatherman, S.P., and Douglas, B.C., 2018, Erosion-Historical analysis and forecasting, in Finkl, C.W., and Makowski, C., eds., Encyclopedia of Coastal Science: Springer International Publishing AG, p. 428-432.

Crowell, Mark, Leatherman, S.P., and Buckley, M.K., 1991, Historical shoreline change-Error analysis and mapping accuracy: Journal of Coastal Research, v. 7, no. 3, p. 839-852.

1993, Shoreline change rate analysisLong term versus short term data: Shore \& Beach, v. 61, no. 2, p. 13-20.

Crowell, Mark, Leikin, H., and Buckley, M.K., 1999, Evaluation of coastal erosion hazards study: an overview: Journal of Coastal Research, special issue no. 28, p. 2-9. 
Douglas, B.C., and Crowell, Mark, 2000, Longterm shoreline position prediction and error propagation: Journal of Coastal Research, v. 16, no. 1 , p. 145-152.

DeGrandpre, K.G., and Freymueller, J.T., 2019, Vertical velocities, glacial isostatic adjustment, and earth structure of northern and westernAlaska based on repeat GPS measurements: Journal of Geophysical Research-Solid Earth 124, 16 p. https://doi.org/10.1029/2018JB017163

Dunham, Lisa, Wartman, Joseph, Olsen, M.J., O'Banion, Matthew, and Cunningham, Keith, 2017, Rockfall activity index (RAI): A lidar-derived, morphology-based method for hazard assessment: Engineering Geology, v. 221, p. 184-192. https://doi.org/10.1016/j.enggeo.2017.03.009

Farquharson, L.M., Mann, D.H., Swanson, D.K., Jones, B.M., Buzard, R.M., and Jordan, J.W., 2018, Temporal and spatial variability in coastline response to declining sea-ice in northwest Alaska: Marine Geology 404, p. 71-83.

Fang, Zhanpei, Freeman, P.T., Field, C.B., and Mach, K.J., 2018, Reduced sea ice protection period increases storm exposure in Kivalina, Alaska: Arctic Science, v. 4, p. 525-537.

Genz, A.S., Fletcher, C.H., Dunn, R.A., Fazer, L.N., and Rooney, J.J., 2007, The predictive accuracy of shoreline change rate methods and alongshore beach variation on Maui, Hawaii: Journal of Coastal Research, v. 23, no. 1, p. 87-105.

Glenn Gray and Associates, 2010, Situation assessment-Kivalina consensus building project: Glenn Gray and Associates, 49 p.

Gorokhovich, Yuri, and Leiserowiz, Anthony, 2012, Historical and future coastal changes in northwest Alaska: Journal of Coastal Research, v. 28, no. 1A, p. 174-186. https://doi.org/10.2112/ JCOASTRES-D-11-00031.1

Hapke, C.J., and Plant, N.G., 2010, Predicting coastal cliff erosion using a Bayesian probabilistic model: Marine Geology 278, p. 140-149. https://doi.org/10.1016/j.margeo.2010.10.001

Herrmann, Victoria, 2017, America's first climate change refugees_-Victimization, distancing, and disempowerment in journalistic storytelling: Energy Research \& Social Science, v. 31, p. 205-214.
Himes-Cornell, A., Hoelting, K., Maquire, C., Munger-Little, L., Lee, J., Fisk, J., Felthoven, R., Geller, C., and Little, P., 2013, Community profiles for North Pacific fisheries-Alaska: NOAA Technical Memorandum NMFS-AFSC-259, v. $12,711 \mathrm{p}$.

Himmelstoss, E.A., Farris, A.S., Henderson, R.E., Kratzmann, M.G., Ergul, Ayhan, Zhang, Ouya, Zichichi, J.L., and Thieler, E.R., 2018, Digital shoreline analysis system (version 5.0): U.S. Geological Survey software release. https://code. usgs.gov/cch/dsas

Hooke, J.M., 2007, Complexity, self-organization and variation in behavior in meandering rivers: Geomorphology 91, p. 236-258.

Immediate Action Working Group (IAWG), 2009, Recommendations report to the governor's sub-cabinet on climate change: Immediate Action Working Group, 168 p. https://dec.alaska. gov/climate-change/

Intergovernmental Panel on Climate Change, 2014, Climate change 2014-Synthesis report: Contribution of working groups I, II and III to the fifth assessment report of the Intergovernmental Panel on Climate Change in Core Writing Team, Pachauri, R.K., and Meyer, L.A., eds., Intergovernmental Panel on Climate Change, Geneva, Switzerland, 151 p.

Irrgang, A.M., Lantuit, Hugues, Gordon, R.R., Piskor, Ashley, and Manson, G.K., 2019, Impacts of past and future coastal changes on the Yukon coast-Threats for cultural sites, infrastructure, and travel routes: Arctic Science 5, p. 107-126. http://doi.org/10.1139/as-2017-0041

Jones, B.M., Farquharson, L.M., Baughman, C.A., Buzard, R.M., Arp, C.D., Grosse, G., Bull, D., Guenther, F., Nitze, I., Urban, F., Kasper, J., Frederick, J.M., Thomas, M., Jones, C., Mota, A., Dallimore, S., Tweedle, C., Maio, C.V., Mann, D.H., Richmond, B., Gibbs, A.E., Xiao, M., Kanevskiy, M., and Romanovsky, V.E., 2018, A decade of remotely sensed observations highlight complex processes linked to coastal permafrost bluff erosion in the Arctic: Environmental Research Letters, v. 13, no. 11, 13 p. 
Kinsman, N.E.M., and Gould, A.I., 2014, Contemporary shoreline retreat rates at Meshik in Port Heiden, Alaska: Alaska Division of Geological \& Geophysical Surveys Preliminary Interpretive Report 2014-4, 21 p. http://doi.org/10.14509/27321 Lagasse, P.F., Spitz, W.J., and Zevenbergen, L.W., 2002, A methodology for predicting channel migration NCHRP Project No. 42-16, in Chen, Hamn-Ching, Briaud, Jean-Louis (Hg.): First International Conference on Scour of Foundations, College Station, Texas, Nov. 17-20, 2002: Texas Transportation Institute, Publications Dept., p. 1,051-1,060.

Lantuit, Hugues, Overduin, P.P., and Wetterich, S., 2013, Recent progress regarding permafrost coasts: Permafrost and Periglacial Processes 24, p. 120-130. http://doi.org/10.1002/ppp. 1777

Larsen, P.H., Goldsmith, S., Smith, O., Wilson, M.L., Strzepek, K., Chinowsky, P., and Saylor, B., 2008, Estimating future costs for Alaska public infrastructure at risk from climate change: Global Environmental Change, v. 18, no. 3, p. 442-457. http://doi.org/10.1016/j. gloenvcha.2008.03.005

Mason, O.K., Jordan, J.W., Lestak, L.R., and Manley, W.F., 2012, Narratives of shoreline erosion and protection at Shishmaref, Alaska-The anecdotal and the analytical, in Cooper, Andrew, and Pilkey, Orrin, eds., Pitfalls of shoreline stabilization: Springer, Dordrecht, p. 73-92.

Native Village of Newtok, AECOM+URS Corporation, and BP\&D, 2015, Newtok Village tribal hazard mitigation plan update: Federal Emergency Management Agency, 82 p.

Overbeck, J.R., 2018, Alaska coastal mapping gaps \& priorities: Alaska Division of Geological \& Geophysical Surveys Information Circular 72. http://doi.org/10.14509/30096

Overbeck, J.R., Buzard, R.M., Turner, M.M., Miller, K.Y., and Glenn, R.J., 2020, Shoreline change at Alaska coastal communities: Alaska Division of Geological \& Geophysical Surveys Report of Investigation 2020-10, 29 p., 47 sheets. https://doi.org/10.14509/30552

Overeem, Irina, Anderson, R.S., Wobus, C.W., Clow, G.D., Urban, F.E., and Matell, Nora, 2011, Sea ice loss enhances wave action at the Arctic coast: Geophysical Research Letters, v. 38, L17503, 6 p. http://doi.org/10.1029/2011GL048681

Perello, Melanie, November 2019, Draft Great Lakes coastal erosion-Review of erosion estimates, mapping, and public policies and outreach across the Great Lakes: Minnesota Department of Natural Resources, Lake Superior Coastal Program, 48 p. http://ardc. org/wp-content/uploads/2020/01/20191105_ ReportOnGreatLakesErosionEfforts.pdf

Ruggiero, Peter, Kaminsky, G.M., Gelfenbaum, Guy, and Voigt, Brian, 2005, Seasonal to interannual morphodynamics along a high-energy dissipative littoral cell: Journal of Coastal Research, v. 21, no. 3, p. 553-578. http://doi. org/10.2112/03-0029.1

Thoman, Rick, and Walsh, J.E., 2019, Alaska's changing environment-Documenting Alaska's physical and biological changes through observations, International Arctic Research Center, University of Alaska Fairbanks, 16 p.

Turnipseed, Christopher, Konsoer, Kory, Richards, Derek, and Willson, Clinton, 2021, Numerical modeling of two-dimensional hydrodynamics in a highly curving and actively evolving neck cutoff under different hydrologic conditions: Water Resources Research, v. 57, 14 p. https://doi. org/10.1029/2020WR027329

U.S. Arctic Research Commission, 2015, Alaskan water and sanitation retrospective 1970-2005: Alaska Rural Water and Sanitation Working Group, 26 p.

U.S. Congress, Office of Technology Assessment, 1994, An Alaskan challenge-Native village sanitation: OTA-ENV-591, Washington, D.C., U.S. Government Printing Office, 126 p.

U.S. General Accounting Office (GAO), 2003, Alaska Native villages: most are affected by flooding and erosion, but few qualify for federal assistance: U.S. General Accounting Office, GAO-04-142, $91 \mathrm{p}$.

2009, Alaska Native villages: limited progress has been made on relocating villages threatened by flooding and erosion: U.S. Government Accountability Office, GAO-09-551, 53 p. 
U.S. Army Corps of Engineers (USACE), 2008, Revised environmental assessment-Finding of no significant impact-Newtok evacuation center Mertarvik, Nelson Island, Alaska: U.S. Army Corps of Engineers Alaska District, $64 \mathrm{p}$.

2009a, Alaska baseline erosion assessmentStudy findings and technical report: U.S. Army Corps of Engineers Alaska District, $65 \mathrm{p}$. 2009b, AVETA report summary-Kivalina, Alaska: U.S. Army Corps of Engineers Alaska District, $4 \mathrm{p}$.
University of Alaska Fairbanks (UAF) Institute of Northern Engineering, U.S. Army Corps of Engineers Alaska District, U.S. Army Corps of Engineers (USACE) Cold Regions Research and Engineering Laboratory, 2019, Statewide threat assessment-identification of threats from erosion, flooding, and thawing permafrost in remote Alaska communities: Report \#INE 19.03, 99 p. Yoder, Sarah, 2018, Assessment of the potential health impacts of climate change in Alaska: State of Alaska Epidemiology Bulletin, v. 20, 77 p. 


\section{APPENDIX A}

Table A1. Summary table of quantity of exposed infrastructure by forecast date range and community. Some items are measured in linear feet (LF) or square feet (SF).

\begin{tabular}{|c|c|c|c|c|c|c|c|}
\hline Community & $\begin{array}{c}\text { Date } \\
\text { Range }\end{array}$ & $\begin{array}{l}\text { Quantity of Exposed } \\
\text { Infrastructure }\end{array}$ & $\begin{array}{l}\text { Date } \\
\text { Range }\end{array}$ & $\begin{array}{l}\text { Quantity of Exposed } \\
\text { Infrastructure }\end{array}$ & $\begin{array}{l}\text { Date } \\
\text { Range }\end{array}$ & $\begin{array}{l}\text { Quantity of Exposed } \\
\text { Infrastructure }\end{array}$ & Other \\
\hline Newtok & $\begin{array}{l}2015 \\
\text { to } \\
2035\end{array}$ & $\begin{array}{l}\text { 2,007 LF Power Line } \\
\text { 1,675 LF Water Line } \\
\text { 6,155 LF Road \& Boardwalk } \\
\text { 38,850 SF Barge Landing } \\
\text { 31 Buildings } \\
1 \text { Tank Facility } \\
\text { 69,320 SF Wastewater Lagoon } \\
\text { 220 LF Airport }\end{array}$ & $\begin{array}{l}2035 \\
\text { to } \\
2055\end{array}$ & $\begin{array}{l}\text { 3,373 LF Power Line } \\
\text { 1,854 LF Water Line } \\
\text { 10,892 LF Road \& Boardwalk } \\
\text { 3,480 SF Barge Landing } \\
\text { 44 Buildings } \\
\text { 1 Tank Facility } \\
\text { 730 LF Airport }\end{array}$ & $\begin{array}{l}2055 \\
\text { to } \\
2075\end{array}$ & $\begin{array}{l}\text { 1,191 LF Power Line } \\
\text { 254 LF Water Line } \\
\text { 1,347 LF Road \& Boardwalk } \\
9 \text { Buildings } \\
1 \text { Tank Facility } \\
\text { 520 LF Airport }\end{array}$ & $\mathrm{n} / \mathrm{a}$ \\
\hline Napakiak & $\begin{array}{l}2015 \\
\text { to } \\
2035\end{array}$ & $\begin{array}{l}983 \text { LF Power Line } \\
598 \text { LF Water Line } \\
\text { 2,091 LF Road } \\
19 \text { Buildings }\end{array}$ & $\begin{array}{l}2035 \\
\text { to } \\
2055\end{array}$ & $\begin{array}{l}\text { 1,117 LF Power Line } \\
\text { 288 LF Water Line } \\
\text { 3,088 LF Road } \\
\text { 25 Buildings } \\
\text { 145,240 SF Landfill }\end{array}$ & $\begin{array}{l}2055 \\
\text { to } \\
2075\end{array}$ & $\begin{array}{l}\text { 1,222 LF Power Line } \\
\text { 2,377 LF Road Line } \\
19 \text { Buildings } \\
1 \text { Tank Facility }\end{array}$ & $\mathrm{n} / \mathrm{a}$ \\
\hline Kotlik & $\begin{array}{l}2015 \\
\text { to } \\
2035\end{array}$ & $\begin{array}{l}892 \text { LF Power Line } \\
31 \text { LF Water Line } \\
242 \text { LF Boardwalk } \\
24 \text { Buildings }\end{array}$ & $\begin{array}{l}2035 \\
\text { to } \\
2055\end{array}$ & $\begin{array}{l}955 \text { LF Power Line } \\
44 \text { LF Water Line } \\
500 \text { LF Boardwalk } \\
26 \text { Buildings }\end{array}$ & $\begin{array}{l}2055 \\
\text { to } \\
2075\end{array}$ & $\begin{array}{l}430 \text { LF Power Line } \\
100 \text { LF Water Line } \\
480 \text { LF Boardwalk } \\
13 \text { Buildings }\end{array}$ & $\mathrm{n} / \mathrm{a}$ \\
\hline Alakanuk & $\begin{array}{l}2015 \\
\text { to } \\
2035\end{array}$ & $\begin{array}{l}40 \text { LF Power Line } \\
10 \text { LF Water Line } \\
530 \text { LF Road } \\
2 \text { Buildings }\end{array}$ & $\begin{array}{l}2035 \\
\text { to } \\
2055\end{array}$ & $\begin{array}{l}\text { 1,330 LF Power Line } \\
280 \text { LF Water Line } \\
\text { 4,100 LF Road } \\
4 \text { Buildings }\end{array}$ & $\begin{array}{l}2055 \\
\text { to } \\
2075\end{array}$ & $\begin{array}{l}\text { 1,689 LF Power Line } \\
3 \text { LF Fuel Line } \\
780 \text { LF Water Line } \\
\text { 1,250 LF Road } \\
13 \text { Buildings }\end{array}$ & $\mathrm{n} / \mathrm{a}$ \\
\hline Egegik & $\begin{array}{l}2018 \\
\text { to } \\
2038\end{array}$ & $\begin{array}{l}73 \text { LF Power Line } \\
\text { 1,545 LF Water Line } \\
539 \text { Road } \\
10 \text { Buildings }\end{array}$ & $\begin{array}{l}2038 \\
\text { to } \\
2058\end{array}$ & $\begin{array}{l}505 \text { LF Power Line } \\
2,715 \text { LF Water Line } \\
763 \text { Road } \\
16 \text { Buildings }\end{array}$ & $\begin{array}{c}2058 \\
\text { to } \\
2078\end{array}$ & $\begin{array}{l}\text { 1,574 LF Power Line } \\
\text { 4,257 LF Water Line } \\
\text { 1,326 Road } \\
8 \text { Buildings }\end{array}$ & $\mathrm{n} / \mathrm{a}$ \\
\hline
\end{tabular}




\begin{tabular}{|c|c|c|c|c|c|c|c|}
\hline Community & $\begin{array}{l}\text { Date } \\
\text { Range }\end{array}$ & $\begin{array}{l}\text { Quantity of Exposed } \\
\text { Infrastructure }\end{array}$ & $\begin{array}{l}\text { Date } \\
\text { Range }\end{array}$ & $\begin{array}{l}\text { Quantity of Exposed } \\
\text { Infrastructure }\end{array}$ & $\begin{array}{l}\text { Date } \\
\text { Range }\end{array}$ & $\begin{array}{l}\text { Quantity of Exposed } \\
\text { Infrastructure }\end{array}$ & Other \\
\hline Kipnuk & $\begin{array}{l}2015 \\
\text { to } \\
2035\end{array}$ & $\begin{array}{l}333 \text { LF Power Line } \\
537 \text { LF Fuel Line } \\
741 \text { LF Road \& Boardwalk } \\
\text { 38,850 SF Barge Landing } \\
\text { 4 Buildings } \\
2 \text { Tank Facilities }\end{array}$ & $\begin{array}{l}2035 \\
\text { to } \\
2055\end{array}$ & $\begin{array}{l}768 \text { LF Power Line } \\
340 \text { LF Fuel Line } \\
1,781 \text { LF Road \& Boardwalk } \\
3,480 \text { SF Barge Landing } \\
9 \text { Buildings } \\
1 \text { Tank Facility }\end{array}$ & $\begin{array}{l}2055 \\
\text { to } \\
2075\end{array}$ & $\begin{array}{l}837 \text { LF Power Line } \\
210 \text { LF Fuel Line } \\
79 \text { LF Water Line } \\
1,928 \text { LF Road \& Boardwalk } \\
17 \text { Buildings }\end{array}$ & $\mathrm{n} / \mathrm{a}$ \\
\hline Tuntutuliak & $\begin{array}{l}2015 \\
\text { to } \\
2035\end{array}$ & $\begin{array}{l}367 \text { LF Power Line } \\
74 \text { LF Fuel Line } \\
110 \text { LF Water Line } \\
622 \text { LF Boardwalk } \\
\text { 22,410 SF Barge Landing } \\
25 \text { Buildings }\end{array}$ & $\begin{array}{l}2035 \\
\text { to } \\
2055\end{array}$ & $\begin{array}{l}\text { 400 LF Power Line } \\
\text { 245 LF Fuel Line } \\
331 \text { LF Water Line } \\
\text { 1,466 LF Boardwalk } \\
\text { 23,256 SF Barge Landing } \\
\text { 27 Buildings } \\
1 \text { Tank Facility }\end{array}$ & $\begin{array}{l}2055 \\
\text { to } \\
2075\end{array}$ & $\begin{array}{l}505 \text { LF Power Line } \\
199 \text { LF Fuel Line } \\
362 \text { LF Water Line } \\
946 \text { LF Boardwalk } \\
\text { 145,237 SF Barge Landing } \\
17 \text { Buildings } \\
13 \text { LF Airport }\end{array}$ & $\mathrm{n} / \mathrm{a}$ \\
\hline Dillingham & $\begin{array}{l}2018 \\
\text { to } \\
2038\end{array}$ & 610 LF Water Line & $\begin{array}{l}2038 \\
\text { to } \\
2058\end{array}$ & $\begin{array}{l}981 \text { LF Water Line } \\
\text { 2,006 SF Wastewater } \\
\text { Lagoon } \\
9 \text { Buildings }\end{array}$ & $\begin{array}{l}2058 \\
\text { to } \\
2078\end{array}$ & $\begin{array}{l}\text { 1,258 LF Water Line } \\
97,854 \text { SF Wastewater } \\
\text { Lagoon } \\
8 \text { Buildings }\end{array}$ & $\mathrm{n} / \mathrm{a}$ \\
\hline Emmonak & $\begin{array}{l}2015 \\
\text { to } \\
2035\end{array}$ & $\begin{array}{l}\text { 3,769 LF Power Line } \\
\text { 37 LF Fuel Line } \\
\text { 27 LF Water Line } \\
\text { 4,279 LF Road } \\
\text { 3 Buildings }\end{array}$ & $\begin{array}{l}2035 \\
\text { to } \\
2055\end{array}$ & $\begin{array}{l}368 \text { LF Power Line } \\
37 \text { LF Fuel Line } \\
71 \text { LF Water Line } \\
\text { 2,225 LF Road } \\
4 \text { Buildings }\end{array}$ & $\begin{array}{l}2055 \\
\text { to } \\
2075\end{array}$ & $\begin{array}{l}637 \text { LF Power Line } \\
37 \text { LF Fuel Line } \\
242 \text { LF Water Line } \\
\text { 1,026 LF Road } \\
14 \text { Buildings }\end{array}$ & $\mathrm{n} / \mathrm{a}$ \\
\hline
\end{tabular}




\begin{tabular}{|c|c|c|c|c|c|c|c|}
\hline Community & $\begin{array}{c}\text { Date } \\
\text { Range }\end{array}$ & $\begin{array}{l}\text { Quantity of Exposed } \\
\text { Infrastructure }\end{array}$ & $\begin{array}{c}\text { Date } \\
\text { Range }\end{array}$ & $\begin{array}{l}\text { Quantity of Exposed } \\
\text { Infrastructure }\end{array}$ & $\begin{array}{c}\text { Date } \\
\text { Range }\end{array}$ & $\begin{array}{l}\text { Quantity of Exposed } \\
\text { Infrastructure }\end{array}$ & Other \\
\hline Hooper Bay & $\begin{array}{l}2015 \\
\text { to } \\
2035\end{array}$ & 9 LF Road & $\begin{array}{l}2035 \\
\text { to } \\
2055\end{array}$ & $\begin{array}{l}209 \text { LF Road } \\
463 \text { LF Airport }\end{array}$ & $\begin{array}{l}2055 \\
\text { to } \\
2075\end{array}$ & $\begin{array}{l}7 \text { LF Fuel Line } \\
116 \text { LF Road } \\
505 \text { LF Airport }\end{array}$ & $\mathrm{n} / \mathrm{a}$ \\
\hline Shishmaref & $\begin{array}{l}2019 \\
\text { to } \\
2039\end{array}$ & $\begin{array}{l}7 \text { LF Water Line } \\
\text { 1,045 LF Road } \\
3 \text { Buildings }\end{array}$ & $\begin{array}{l}2039 \\
\text { to } \\
2059\end{array}$ & $\begin{array}{l}522 \text { LF Road } \\
2 \text { Buildings } \\
18 \text { SF Wastewater Lagoon }\end{array}$ & $\begin{array}{l}2059 \\
\text { to } \\
2079\end{array}$ & $\begin{array}{l}249 \text { LF Power Line } \\
488 \text { LF Road } \\
2 \text { Buildings } \\
\text { 3,935 SF Wastewater } \\
\text { Lagoon }\end{array}$ & $\mathrm{n} / \mathrm{a}$ \\
\hline Kwigillingok & $\begin{array}{l}2015 \\
\text { to } \\
2035\end{array}$ & $\begin{array}{l}47 \text { LF Power Line } \\
\text { 1,109 LF Road \& Boardwalk } \\
\text { 18,388 SF Barge Landing } \\
5 \text { Buildings }\end{array}$ & $\begin{array}{l}2035 \\
\text { to } \\
2055\end{array}$ & $\begin{array}{l}492 \text { LF Power Line } \\
62 \text { LF Water Line } \\
1,187 \text { LF Road \& Boardwalk } \\
9 \text { Buildings }\end{array}$ & $\begin{array}{l}2055 \\
\text { to } \\
2075\end{array}$ & $\begin{array}{l}\text { 1,593 LF Power Line } \\
385 \text { LF Water Line } \\
\text { 1,910 LF Road \& Boardwalk } \\
21 \text { Buildings }\end{array}$ & $\begin{array}{c}\text { River Migration } \\
\text { Hazard } \\
103 \text { LF Power } \\
459 \text { LF Road \& } \\
\text { Boardwalk } \\
3 \text { Buildings }\end{array}$ \\
\hline Point Hope & $\begin{array}{l}2019 \\
\text { to } \\
2039\end{array}$ & 282 LF Airport & $\begin{array}{l}2039 \\
\text { to } \\
2059\end{array}$ & 231 LF Airport & $\begin{array}{l}2059 \\
\text { to } \\
2079\end{array}$ & 191 LF Airport & $\mathrm{n} / \mathrm{a}$ \\
\hline Chefornak & $\begin{array}{l}2015 \\
\text { to } \\
2035\end{array}$ & $\begin{array}{l}65 \text { LF Fuel Line } \\
7 \text { LF Road \& Boardwalk } \\
\text { 5,969 SF Barge Landing } \\
5 \text { Buildings }\end{array}$ & $\begin{array}{l}2035 \\
\text { to } \\
2055\end{array}$ & $\begin{array}{l}65 \text { LF Fuel Line } \\
7 \text { LF Road \& Boardwalk } \\
6,680 \text { SF Barge Landing } \\
6 \text { Buildings }\end{array}$ & $\begin{array}{l}2055 \\
\text { to } \\
2075\end{array}$ & $\begin{array}{l}149 \text { LF Fuel Line } \\
7 \text { LF Road \& Boardwalk } \\
6,410 \text { SF Barge Landing } \\
9 \text { Buildings }\end{array}$ & $\mathrm{n} / \mathrm{a}$ \\
\hline Kongiganak & $\begin{array}{l}2015 \\
\text { to } \\
2035\end{array}$ & $\begin{array}{l}\text { 158 LF Power Line } \\
13 \text { LF Road \& Boardwalk } \\
\text { 3,114 SF Barge Landing }\end{array}$ & $\begin{array}{l}2035 \\
\text { to } \\
2055\end{array}$ & $\begin{array}{l}\text { 224 LF Power Line } \\
\text { 333 LF Road \& Boardwalk } \\
\text { 2,977 SF Barge Landing }\end{array}$ & $\begin{array}{l}2055 \\
\text { to } \\
2075\end{array}$ & $\begin{array}{l}180 \text { LF Power Line } \\
18 \text { LF Fuel Line } \\
79 \text { LF Water Line } \\
197 \text { LF Road \& Boardwalk } \\
\text { 2,608 SF Barge Landing } \\
1 \text { Building } \\
1 \text { Tank Facility }\end{array}$ & $\mathrm{n} / \mathrm{a}$ \\
\hline
\end{tabular}




\begin{tabular}{|c|c|c|c|c|c|c|c|}
\hline Community & $\begin{array}{l}\text { Date } \\
\text { Range }\end{array}$ & $\begin{array}{l}\text { Quantity of Exposed } \\
\text { Infrastructure }\end{array}$ & $\begin{array}{l}\text { Date } \\
\text { Range }\end{array}$ & $\begin{array}{l}\text { Quantity of Exposed } \\
\text { Infrastructure }\end{array}$ & $\begin{array}{l}\text { Date } \\
\text { Range }\end{array}$ & $\begin{array}{l}\text { Quantity of Exposed } \\
\text { Infrastructure }\end{array}$ & Other \\
\hline Nunam lqua & $\begin{array}{l}2019 \\
\text { to } \\
2039\end{array}$ & $\begin{array}{l}294 \text { LF Power Line } \\
63 \text { LF Fuel Line } \\
201 \text { LF Water Line } \\
270 \text { LF Boardwalk } \\
6 \text { Buildings } \\
853 \text { SF Airport } \\
\text { 13,750 SF Barge Landing }\end{array}$ & $\begin{array}{l}2039 \\
\text { to } \\
2059\end{array}$ & $\begin{array}{l}471 \text { LF Power Line } \\
63 \text { LF Fuel Line } \\
321 \text { LF Water Line } \\
610 \text { LF Boardwalk } \\
5 \text { Buildings } \\
\text { 1,163 SF Airport } \\
\text { 9,530 SF Barge Landing }\end{array}$ & $\begin{array}{l}2059 \\
\text { to } \\
2079\end{array}$ & $\begin{array}{l}98 \text { LF Power Line } \\
96 \text { LF Fuel Line } \\
537 \text { LF Water Line } \\
849 \text { LF Boardwalk } \\
3 \text { Buildings } \\
\text { 1,564 SF Airport } \\
\text { 4,760 SF Barge Landing }\end{array}$ & $\mathrm{n} / \mathrm{a}$ \\
\hline Clark's Point & $\begin{array}{l}2018 \\
\text { to } \\
2038\end{array}$ & 11 Buildings & $\begin{array}{l}2038 \\
\text { to } \\
2058\end{array}$ & $\begin{array}{l}404 \text { LF Water Line } \\
13 \text { LF Road } \\
4 \text { Buildings }\end{array}$ & $\begin{array}{l}2058 \\
\text { to } \\
2078\end{array}$ & $\begin{array}{l}261 \text { LF Water Line } \\
14 \text { LF Road } \\
1 \text { Building }\end{array}$ & $\mathrm{n} / \mathrm{a}$ \\
\hline Ekuk & $\begin{array}{l}2018 \\
\text { to } \\
2038\end{array}$ & $\begin{array}{l}254 \text { LF Power Line } \\
13 \text { Buildings }\end{array}$ & $\begin{array}{l}2038 \\
\text { to } \\
2058\end{array}$ & $\begin{array}{l}336 \text { LF Power Line } \\
86 \text { LF Airport } \\
10 \text { Buildings } \\
1 \text { Tank Facility }\end{array}$ & $\begin{array}{l}2058 \\
\text { to } \\
2078\end{array}$ & $\begin{array}{l}180 \text { LF Power Line } \\
145 \text { LF Airport } \\
14 \text { Buildings }\end{array}$ & $\mathrm{n} / \mathrm{a}$ \\
\hline Pilot Point & $\begin{array}{l}2019 \\
\text { to } \\
2039\end{array}$ & 1,859 LF Road & $\begin{array}{l}2039 \\
\text { to } \\
2059\end{array}$ & $\begin{array}{l}682 \text { LF Road } \\
1 \text { Bulkhead }\end{array}$ & $\begin{array}{l}2059 \\
\text { to } \\
2079\end{array}$ & 964 LF Road & $\mathrm{n} / \mathrm{a}$ \\
\hline Stebbins & $\begin{array}{l}2015 \\
\text { to } \\
2035\end{array}$ & $\begin{array}{l}3 \text { LF Road } \\
7 \text { Buildings }\end{array}$ & $\begin{array}{l}2035 \\
\text { to } \\
2055\end{array}$ & $\begin{array}{l}3 \text { LF Road } \\
6 \text { Buildings }\end{array}$ & $\begin{array}{l}2055 \\
\text { to } \\
2075\end{array}$ & $\begin{array}{l}3 \text { LF Road } \\
5 \text { Buildings }\end{array}$ & $\mathrm{n} / \mathrm{a}$ \\
\hline Naknek & $\begin{array}{l}2018 \\
\text { to } \\
2038\end{array}$ & $\begin{array}{l}48 \text { LF Road } \\
2 \text { Buildings }\end{array}$ & $\begin{array}{l}2038 \\
\text { to } \\
2058\end{array}$ & $\begin{array}{l}3 \text { LF Power Line } \\
83 \text { LF Road } \\
3 \text { Buildings }\end{array}$ & $\begin{array}{l}2058 \\
\text { to } \\
2078\end{array}$ & $\begin{array}{l}94 \text { LF Road } \\
3 \text { Buildings }\end{array}$ & $\mathrm{n} / \mathrm{a}$ \\
\hline Port Heiden & $\begin{array}{l}2019 \\
\text { to } \\
2039\end{array}$ & $\begin{array}{l}482 \text { LF Road } \\
1 \text { Barge Landing }\end{array}$ & $\begin{array}{l}2039 \\
\text { to } \\
2059\end{array}$ & $\begin{array}{l}922 \text { LF Road } \\
1 \text { Building }\end{array}$ & $\begin{array}{l}2059 \\
\text { to } \\
2079\end{array}$ & Not Assessed & $\mathrm{n} / \mathrm{a}$ \\
\hline
\end{tabular}




\begin{tabular}{|c|c|c|c|c|c|c|c|}
\hline Community & $\begin{array}{l}\text { Date } \\
\text { Range }\end{array}$ & $\begin{array}{c}\text { Quantity of Exposed } \\
\text { Infrastructure }\end{array}$ & $\begin{array}{l}\text { Date } \\
\text { Range }\end{array}$ & $\begin{array}{l}\text { Quantity of Exposed } \\
\text { Infrastructure }\end{array}$ & $\begin{array}{c}\text { Date } \\
\text { Range }\end{array}$ & $\begin{array}{l}\text { Quantity of Exposed } \\
\text { Infrastructure }\end{array}$ & Other \\
\hline Levelock & $\begin{array}{l}2018 \\
\text { to } \\
2038\end{array}$ & $\begin{array}{l}51 \text { LF Boat Launch } \\
3 \text { Buildings }\end{array}$ & $\begin{array}{l}2038 \\
\text { to } \\
2058\end{array}$ & $\begin{array}{l}48 \text { LF Boat Launch } \\
1 \text { Building }\end{array}$ & $\begin{array}{l}2058 \\
\text { to } \\
2078\end{array}$ & $\begin{array}{l}45 \text { LF Power Line } \\
31 \text { LF Boat Launch }\end{array}$ & $\mathrm{n} / \mathrm{a}$ \\
\hline Kaktovik & $\begin{array}{l}2019 \\
\text { to } \\
2039\end{array}$ & $\begin{array}{l}19 \text { LF Water Line } \\
220 \text { LF Road }\end{array}$ & $\begin{array}{l}2039 \\
\text { to } \\
2059\end{array}$ & $\begin{array}{l}17 \text { LF Water Line } \\
400 \text { LF Road } \\
1 \text { Fuel Header }\end{array}$ & $\begin{array}{l}2059 \\
\text { to } \\
2079\end{array}$ & $\begin{array}{l}17 \text { LF Water Line } \\
\text { 2,262 LF Road }\end{array}$ & $\mathrm{n} / \mathrm{a}$ \\
\hline Wainwright & $\begin{array}{l}2019 \\
\text { to } \\
2039\end{array}$ & $\begin{array}{l}4 \text { LF Water Line } \\
13 \text { LF Road }\end{array}$ & $\begin{array}{l}2039 \\
\text { to } \\
2059\end{array}$ & $\begin{array}{l}24 \text { LF Power Line } \\
118 \text { LF Water Line } \\
60 \text { LF Road }\end{array}$ & $\begin{array}{l}2059 \\
\text { to } \\
2079\end{array}$ & $\begin{array}{l}66 \text { LF Power Line } \\
219 \text { LF Water Line } \\
238 \text { LF Road } \\
1 \text { Building }\end{array}$ & $\mathrm{n} / \mathrm{a}$ \\
\hline Scammon Bay & $\begin{array}{l}2015 \\
\text { to } \\
2035\end{array}$ & 33 LF Road & $\begin{array}{l}2035 \\
\text { to } \\
2055\end{array}$ & $\begin{array}{l}42 \text { LF Road } \\
26 \text { LF Airport }\end{array}$ & $\begin{array}{l}2055 \\
\text { to } \\
2075\end{array}$ & $\begin{array}{l}48 \text { LF Road } \\
25 \text { LF Airport }\end{array}$ & $\mathrm{n} / \mathrm{a}$ \\
\hline Eek & $\begin{array}{l}2015 \\
\text { to } \\
2035\end{array}$ & $\begin{array}{l}2 \text { LF Water Line } \\
9 \text { LF Road } \\
1 \text { Building }\end{array}$ & $\begin{array}{l}2035 \\
\text { to } \\
2055\end{array}$ & 19 LF Road & $\begin{array}{l}2055 \\
\text { to } \\
2075\end{array}$ & 20 LF Road & $\mathrm{n} / \mathrm{a}$ \\
\hline South Naknek & $\begin{array}{l}2018 \\
\text { to } \\
2038\end{array}$ & 22 LF Road & $\begin{array}{l}2038 \\
\text { to } \\
2058\end{array}$ & 39 LF Road & $\begin{array}{l}2058 \\
\text { to } \\
2078\end{array}$ & $\begin{array}{l}45 \text { LF Road } \\
1 \text { Building }\end{array}$ & $\mathrm{n} / \mathrm{a}$ \\
\hline Toksook Bay & $\begin{array}{l}2015 \\
\text { to } \\
2035\end{array}$ & 18 LF Road & $\begin{array}{l}2035 \\
\text { to } \\
2055\end{array}$ & $\begin{array}{l}13 \text { LF Road } \\
1 \text { Building }\end{array}$ & $\begin{array}{l}2055 \\
\text { to } \\
2075\end{array}$ & $\begin{array}{l}19 \text { LF Road } \\
4 \text { Buildings }\end{array}$ & $\mathrm{n} / \mathrm{a}$ \\
\hline Tununak & $\begin{array}{l}2015 \\
\text { to } \\
2035\end{array}$ & $\begin{array}{l}213 \text { LF Road } \\
1 \text { Bridge }\end{array}$ & $\begin{array}{l}2035 \\
\text { to } \\
2055\end{array}$ & 26 LF Road & $\begin{array}{l}2055 \\
\text { to } \\
2075\end{array}$ & 66 LF Road & $\mathrm{n} / \mathrm{a}$ \\
\hline
\end{tabular}




\begin{tabular}{|c|c|c|c|c|c|c|c|}
\hline Community & $\begin{array}{l}\text { Date } \\
\text { Range }\end{array}$ & $\begin{array}{l}\text { Quantity of Exposed } \\
\text { Infrastructure }\end{array}$ & $\begin{array}{l}\text { Date } \\
\text { Range }\end{array}$ & $\begin{array}{l}\text { Quantity of Exposed } \\
\text { Infrastructure }\end{array}$ & $\begin{array}{l}\text { Date } \\
\text { Range }\end{array}$ & $\begin{array}{l}\text { Quantity of Exposed } \\
\text { Infrastructure }\end{array}$ & Other \\
\hline Koyuk & $\begin{array}{c}2015 \\
\text { to } \\
2035\end{array}$ & 13 LF Road & $\begin{array}{l}2035 \\
\text { to } \\
2055\end{array}$ & 21 LF Road & $\begin{array}{l}2055 \\
\text { to } \\
2075\end{array}$ & 20 LF Road & $\mathrm{n} / \mathrm{a}$ \\
\hline Point Lay & $\begin{array}{c}2019 \\
\text { to } \\
2039\end{array}$ & None & $\begin{array}{l}2039 \\
\text { to } \\
2059\end{array}$ & 79 LF Water Line & $\begin{array}{l}2059 \\
\text { to } \\
2079\end{array}$ & 88 LF Water Line & $\mathrm{n} / \mathrm{a}$ \\
\hline Golovin & \multicolumn{7}{|c|}{ No infrastructure exposed to erosion } \\
\hline Goodnews Bay & \multicolumn{7}{|c|}{ No infrastructure exposed to erosion } \\
\hline St. Michael & \multicolumn{7}{|c|}{ No infrastructure exposed to erosion } \\
\hline Elim & \multicolumn{7}{|c|}{ No significant erosion found with shoreline change method } \\
\hline Kivalina & \multicolumn{7}{|c|}{ No significant erosion found with shoreline change method } \\
\hline Togiak & \multicolumn{7}{|c|}{ No significant erosion found with shoreline change method } \\
\hline Twin Hills & \multicolumn{7}{|c|}{ No significant erosion found with shoreline change method } \\
\hline Deering & \multicolumn{7}{|c|}{ Cannot assess erosion exposure with shoreline change method } \\
\hline Kotzebue & \multicolumn{7}{|c|}{ Cannot assess erosion exposure with shoreline change method } \\
\hline Nome & \multicolumn{7}{|c|}{ Cannot assess erosion exposure with shoreline change method } \\
\hline Shaktoolik & \multicolumn{7}{|c|}{ Cannot assess erosion exposure with shoreline change method } \\
\hline
\end{tabular}

